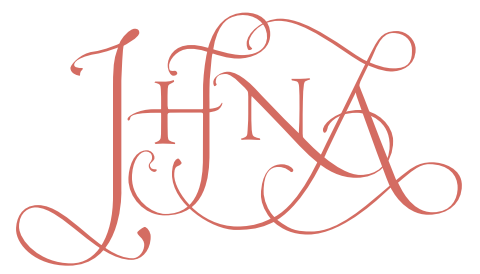

JOURNAL OF HISTORIANS OF NETHERLANDISH ART

Volume 1, Issue 2 (Summer 2009)

\title{
On Brabant Rubbish, Economic Competition, Artistic Rivalry, and the Growth of the Market for Paintings in the First Decades of the Seventeenth Century
}

Eric Jan Sluijter

Recommended Citation:

Eric Jan Sluijter, "On Brabant Rubbish, Economic Competition, Artistic Rivalry, and the Growth of the Market for Paintings in the First Decades of the Seventeenth Century," JHNA 1:2 (Summer 2009), DOI: 10.5092/jhna.2009.1.2.4

Available at https://jhna.org/articles/brabant-rubbish-economic-competition-artistic-rivalry-growth-market-paintings-first-decades-seventeenth-century/

Published by Historians of Netherlandish Art: https://hnanews.org/ Republication Guidelines: https://jhna.org/republication-guidelines/

Notes: This PDF is provided for reference purposes only and may not contain all the functionality or features of the original, online publication. This is a revised PDF that may contain different page numbers from the previous version. Use electronic searching to locate passages. This PDF provides paragraph numbers as well as page numbers for citation purposes.

ISSN: 1949-9833 


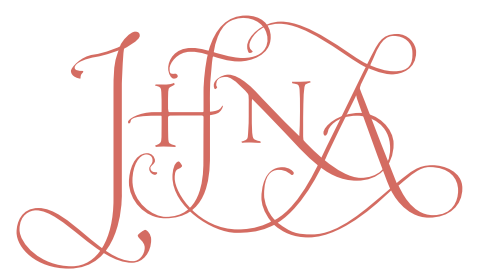

JOURNAL OF HISTORIANS OF NETHERLANDISH ART

\section{ON BRABANT RUBBISH, ECONOMIC COMPETITION, ARTISTIC RI- VALRY, AND THE GROWTH OF THE MARKET FOR PAINTINGS IN THE FIRST DECADES OF THE SEVENTEENTH CENTURY}

\section{Eric Jan Sluijter}

English translation of E. J. Sluijter, "Over Brabantse vodden, economische concurrentie, artistieke wedijver en de groei van de markt voor schilderijen in de eerste decennia van de zeventiende eeuw," in Kunst voor de markt, ed. R. Falkenburg, J. de Jong, and B. Ramakers, Nederlands Kunsthistorisch Jaarboek 50 (1999): 112-43. The text was translated by Jennifer Kilian and Katy Kist with footnotes translated by the author.

This essay presents observations on how and why the number of painters and the production of paintings in Holland increased so spectacularly around 1610. It also discusses the technical changes, the economic competition, and the artistic emulation related to this increase. It is argued that the sudden wave of inexpensive paintings from Antwerp that flooded the Dutch art markets in the first years of the Twelve Years Truce - paintings which seem to have been bought avidly by immigrants from the Southern Netherlands in particular - functioned as a booster. Decorating the house with a variety of rather inexpensive paintings, something the immigrants were already familiar with, caught on with the native population. Second generation immigrants took advantage of this profitable gap in the market and competed with the imported works by producing paintings with similar techniques and subjects, but of a higher quality.

DOl 10.5092/jhna.2009.1.2.4

\section{Introduction}

$1 T$ riting in 1678, Samuel van Hoogstraten noted that "In the beginning of this century, Holland's walls were not as densely hung with paintings as they are now." He continued, "However, this custom crept in more and more every day, seriously spurring some artists to learn to paint quickly, indeed to make a work, whether large or small, every day." He ends this passage by saying that "seeking both profit and fame," a wager was ultimately made as to who could fashion the best painting between sunrise and sunset, following which Van Hoogstraten recounted the famous anecdote about the competition between Porcellis, Van Goyen, and Knibbergen. ${ }^{1}$ The above suggests that Van Hoogstraten was aware of the fact that people had been filling their houses with increasing numbers of paintings as of the beginning of the century, a development he links with the emergence of a rapid production technique. He also posits that financial profit was not the sole motive for painting more quickly, but that the desire to attain fame was a factor as well. Finally, in pursuit of fame, artistic rivalry, too, proves to have played an important role. Van Hoogstraten's remarks encompass all of the elements that interest me here: the fashion of decorating houses with a great many paintings, the spectacular growth in their 
production and the attendant technical innovations, economic competition, and artistic rivalry.

2 Various sources make it clear that the rise in the number of painters embarking on their career in Holland's major cities between roughly 1600 and 1630 was explosive. ${ }^{2}$ That both the quantity as well as the quality of their production reached unprecedented heights is evidenced by the multitude of paintings now hanging in our museums. The whys and wherefores of this astonishing phenomenon will always remain a point of discussion: countless factors, many of which defy description, may have played a role. However, a few concrete reasons will be examined below, preceded by questions concerning contemporary perception of this phenomenon and followed by some thoughts on the underlying causes and the special nature of the related "process and product innovations." On the basis of generally familiar sources, several hypotheses are launched that warrant further elaboration.

\section{I}

Addressing the aforementioned phenomenon, it must be understood that we are not alone in our present-day observation that something quite exceptional was transpiring in Dutch art of the seventeenth century. Contemporaries were also aware of the exceptional nature and quality of painting as well as the astounding growth in the production and collecting of the actual works of art, as indicated by Van Hoogstraten's above-cited account. In this connection, the frequently quoted observations in the travel diaries of the Englishmen John Evelyn (1641) and Peter Mundy (1640) and the Frenchman Samuel Sorbière (1640) must be mentioned. Their comments regarding the vast amount of paintings they encountered everywhere in Dutch cities, and about which they wrote with sheer astonishment, must have become commonplace at the time. Quite likely a proud awareness of this phenomenon was already imbedded in the self-image of the prosperous Dutch burgher.

When Peter Mundy wrote that all the Dutch were striving to adorn their houses, particularly the rooms facing the street, with paintings, and that even butchers, smiths, and cobblers had a few paintings in their stores or workshops, he wished to assure his readers that "Such is the generall Notion, enclination and delight that these Countrie Natives have to Paintings." These lines underscore his statement: "As For the art off Painting and the affection of the people to Pictures, I thincke none other goe beeyond them."3 Sorbière noted an "excessive curiosit é pour les peintures" in the Netherlands. ${ }^{4}$ From the wealthy patrician elite to well-to-do craftsmen, the interest of the Dutch in paintings, however it is described, "inclination," "delight," "affection," or "excessive curiosity," was clearly perceived as highly exceptional and had become part of the stereotyping of this somewhat curious people as seen through the eyes of foreigners. ${ }^{5}$

5 The omnipresence of paintings is also evidenced by the heated reactions of individuals who condemned the art of painting on moral and religious grounds as nothing but "deception." As early as 1624, the ire of Dirck Raphaelsz. Camphuyzen, an extremist in this matter, was roused because the art of painting was so well-liked that one could say nothing against it: "Painting! ha, who can denounce it without [inciting] general rebellion?" One can turn nowhere without seeing pictures: "The whole world depends on engraving, drawing, painting," he cries out in despair. "Painting is the common bait for the uneasy heart overwhelmed by choice, / That despite having to meet essential needs charms the money out of one's purse, / Painting seems to be the sauce 
for all that sprouts from the human mind."6 His comments make all the more clear the extent to which this art served as an important source of amusement for his Dutch contemporaries. That they purchased paintings in large quantities and took pride in the renown of their painting fellow townsmen enraged Camphuyzen beyond reason.

6 As for positive testimonials by compatriots, those of Constantijn Huygens, a connoisseur par excellence, are undoubtedly the most interesting. In the autobiography of his youth, which he began in 1629 and continued until 1631, he remarked that his fellow countrymen had attained greater heights than anyone else - including the ancients, he adds - "in the art of rendering everything with a fresh, lifelike draughtsmanship: every shape and every pose of humans and animals, as well as trees, rivers, mountains and all such things as one sees in a landscape."7 Further on he comments that landscape painters "in the present Netherlands are so tremendously plentifully represented and of such high quality that it would take an entire book to discuss them all individually." History painters in the Netherlands, he continues, are no less numerous and no less successful. ${ }^{8}$ In his discourse, Huygens makes no distinction between his fellow countrymen in the Northern or Southern Netherlands, though only a fraction of the painters he mentions - naturally, including his idol Rubens - were active in the south at the time.

$7 \quad$ Published appreciations of Dutch painting as a source of pride and self-respect already had a tradition in the Netherlands. Praising Netherlandish artists, incidentally, began with an Italian, Ludovico Guicciardini. In the section on Antwerp in his 1567 description of the Netherlands, he touted Antwerp artists as well as other artists from the Lowlands. Around the same time Hadrianus Junius in his Batavia incorporated short biographies of famous artists (alongside those of scholars), deeming them exemplary of the "Hollandica ingenia."' Subsequently, against the backdrop of rivalry with Italy, Karel Van Mander extolled Netherlandish painters for his contemporaries and for future generations in his 1604 Levens. Their fame had already been propagated pictorially a few decades earlier: first in a series of twenty-three portrait prints, with short laudatory poems composed by Domenicus Lampsonius, published by Hieronymus Cock in Antwerp and later, in 1610, in a considerably extended series of sixty-eight portrait prints published by Hendrik Hondius in The Hague. ${ }^{10}$

8 The idea that the art of painting contributed to their renown became so firmly entrenched in the civic pride of towns such as Antwerp, Amsterdam, Leiden and Haarlem that eulogies of painting and its practitioners became a standard feature in city descriptions. Again, this began in Antwerp with Carolus Scribanius's chapter on the Ars Pictoria in his Antverpia of $1610 .{ }^{11}$ A year later Johannes Pontanus incorporated a brief account of painters in his description of Amsterdam, and in 1614 Jan Orlers followed with a much more comprehensive expos é in his book on Leiden. Haarlem artists were extensively discussed by Samuel Ampzing in 1628. Orlers substantially expanded the Leiden canon in 1641 and was succeeded in 1648 by Theodorus Schrevelius, who revisited the merits of Haarlem's painters. ${ }^{12}$ In some of these descriptions the authors even boast that the nation's best painters issued from the city in question. ${ }^{13}$ Pride in the art of painting and the awareness that something special was happening in this regard must have become firmly rooted in the self-image of the elite, first in Antwerp and subsequently in the most important Dutch towns.

9 These panegyrics devoted ever more space to painters who specialized in new kinds of subject 
matter, such as landscapes or peasant scenes. As he did with the history painters, Scribanius compares Joachim Beuckelaer and Pieter Balten with masters from classical antiquity, whom he says they had surpassed. He also commends the landscapists Joachim Patinir and Cornelis Molenaer. ${ }^{14}$ Ampzing even claims that landscape painting was invented in Haarlem, ${ }^{15}$ and Orlers allots Jan van Goyen and Pieter de Neyn a no less exalted position than that of history painters. The public praise and appreciation that comes to the fore in these prestigious city descriptions no doubt amplified the painters' self-respect, but it would also - and this applies to both history painters and specialists - have fueled their ambitions and stimulated their ideas regarding artistic emulation.

10 Constantijn Huygens's words are evidence that a connoisseur from the most elevated, elite burgher circles was proud to count painters among his friends. After mentioning that he always enjoys the company of illustrious men, Huygens states that he wishes to consider more extensively the most prominent painters of his time, the majority of whom, including the ubiquitous De Gheyn and the young and highly ambitious history painters Rembrandt and Lievens, he claims are good friends. ${ }^{16}$ The artists he discusses include not only eminent individuals such as Rubens (it was Huygens's greatest wish to become personally well-acquainted with him) and the aforementioned masters but also specialists, such as the portraitist Michiel van Mierevelt, the marine painter Jan Porcellis, and the landscapist Esaias van de Velde. Clearly, in 1629, Huygens believed that the quality, quantity, and diversity of painting had already increased substantially in his lifetime: he was a mere thirty-three at the time. In his treatment of celebrated Dutch painters, Huygens definitely thought in terms of rivalry - not only Dutch painting vis- à-vis antiquity and Italy but also the painters vis- à-vis each other - which comes emphatically to the fore when he speaks - repeatedly - about one artist having surpassed another in some area. ${ }^{17}$

11 That the best-known seventeenth-century anecdote regarding competition has to do with marine and landscape painters and that Samuel van Hoogstraten simultaneously links the tremendous increase in production with painting at an accelerated pace, thus, seems entirely appropriate.

\section{II}

12 Still, just how did the art of painting come to occupy such an important place in the consciousness of well-to-do Dutch city dwellers, and why did they, from regents and wealthy merchants to trained craftsmen, fairly suddenly and in increasingly greater numbers begin to buy paintings by living masters to adorn the walls of their houses, paintings depicting a growing variety of subjects in different sizes, techniques, and prices? At times the figures are simply astounding. In the middle of the seventeenth century some interiors had thirty to fifty paintings per room, rooms which, it should be noted, were not all that spacious. In such a case, the number of paintings owned could total 150 to $250 .{ }^{18}$ The travelers' amazement at what they saw in the Netherlands is quite understandable. After all, in other European countries paintings were still largely produced for religious institutions, the aristocracy, and royal courts. Moreover, insofar as painters were employed in countries such as England, Germany, and Scandinavia, they were often recruited from the Netherlands.

13 Evidently, in the first decades of the seventeenth century the production of paintings for the homes of the citizenry began fairly suddenly to fill a gap in the market, primarily in the form of 
work by local artists. In Haarlem, the increase in the number of painters far surpassed the concurrent substantial growth of the population. Marion Boers calculated that the number of active painters per one thousand inhabitants more or less octupled between 1605 and 1635: their number almost doubled between 1605 and 1615 (particularly between 1610 and 1615), experienced steady growth between 1615 and 1625, and finally surged between 1625 and $1635 .{ }^{19}$ Admittedly, Haarlem was not your average town in terms of the art of painting, however, in terms of the number of painters per thousand inhabitants, the other major Dutch towns probably did not score much lower. ${ }^{20}$ Boers also calculated that as of 1615 the number of painters in Haarlem increased much faster than the number of silver and gold smiths - skilled craftsmen in another luxury industry - who were twice as numerous in the first decade of the century.

14 This tremendous rise in the number of painters and their production has been attributed primarily to the substantial rise in the purchasing power of the middle classes. ${ }^{21} \mathrm{~A}$ growing demand for luxury items, however, did not necessarily have to be satisfied with paintings. The well-to-do burgher could have done without and decorated his walls with tapestries instead, as was - and remained - the custom among the aristocracy. ${ }^{22}$ The latter fact emerges in Thera Wijsenbeek-Olthuis's investigation of the inventories of aristocratic residents of The Hague's Lange Voorhout in the seventeenth century. In addition to tapestries, the aristocracy usually hung portraits on the wall; generally their interiors included very few paintings with other subjects. In contrast, wealthy Hague magistrates and the affluent middle class owned considerably more paintings, though far fewer portraits. ${ }^{23}$

15 In analysing the expansion of the art market, scholars such as John Michael Montias, Jan de Vries, and Marten Jan Bok focused primarily on the economic dynamics. Yet, they all noted the immense importance of the influx of artists who were part of the wave of immigrants from Brabant and Flanders, a wave that peaked in the second half of the 1580 s. $^{24}$ The crucial impact this had on the development of art in the north has been frequently investigated. Jan Briels in particular has placed great emphasis on immigration and twice constructed an impressive history of Northern Netherlandish art on the basis of artists originally from the Southern Netherlands. ${ }^{25}$ The majority of the Brabant and Flemish immigrants - Briels's earlier studies, incidentally, constitute a rich source of information on the immigration itself ${ }^{26}$ - settled in Amsterdam, Leiden, Haarlem, and Delft, cities of which half to two-thirds of the population consisted of inhabitants with Southern Netherlandish roots at the beginning of the century.

16 Examining more closely the painters active in Dutch cities around the turn of the century shows that the number of those actually originating from the Southern Netherlands is, however, fairly disappointing, certainly with respect to artists whose works are known either from archival records or in actuality and who were thus undoubtedly active as painters. But for a few exceptions, at that point in time the southerners did not yet figure prominently in the fine arts, and one has the impression that the demand was largely satisfied by indigenous painters. ${ }^{27}$ However, when the number of painters did truly grow explosively from 1610 on, especially in Haarlem and Amsterdam, ${ }^{28}$ among this group were many children of immigrants with Southern Netherlandish roots who had opted to become painters and were indeed manifestly successful. ${ }^{29}$ Although some of these painters were born in the south, they were trained in Holland. Interestingly, within this generation the more traditional genres of the profession, the painting of histories and of portraits, 
remained largely in the hands of native painters, while the new specialities, particularly landscape and still-life painting were primarily cultivated by the young southerners.

\section{III}

17 To better understand what happened, we must first concentrate on the public: the buyers of paintings. Amsterdam, Haarlem, and Leiden in particular had drawn a large number of immigrant merchants and highly trained artisans (many from Antwerp, especially in Amsterdam), whose purchasing power must have increased substantially in the two previous decades. They came from a culture in which it had become common for affluent burghers to buy paintings to embellish their homes as early as the second half of the sixteenth century. ${ }^{30}$ Moreover, they were accustomed to these decorations portraying profane subjects as well as being available in various price ranges, from exorbitantly expensive to extremely cheap. After all, vast quantities of landscapes, peasant scenes, and kitchen still lifes varying greatly in quality were already being produced in Antwerp and Malines in the second half of the sixteenth century.

18 For these immigrants there was probably not that much to buy just yet in the cities of their new homeland. In the late sixteenth century most of the painters in Holland seem to have primarily made fairly expensive history paintings destined for a select group of connoisseurs. Moreover, initially the immigrants will have had matters other than purchasing paintings on their minds. Presumably, as long as these refugees believed that their sojourn in Holland was temporary and their return to their former abodes imminent (a situation which must have lasted quite a long time), they elected not to spend their money on luxury articles to decorate their homes but rather on easily transportable valuables. Only when the hope or wish to return had vanished, and they had definitely resigned themselves to staying (which must have been around the time of the Twelve Years' Truce), ${ }^{31}$ will their desire to adorn their interiors have grown. And, as is revealed below, the immigrants were given the opportunity of doing so at just that moment.

19 As of 1608, and thus still shortly before the signing of the Twelve Years' Truce, a large number of paintings appears to have suddenly begun flowing from Antwerp to the Republic, flooding the market in the Dutch cities. These were inexpensive works that - at least in the eyes of Dutch burghers - were sold in an unusual way. ${ }^{32}$ The established painters seem to have been startled, to say the least, and responded vehemently. In Amsterdam and Leiden they demanded that the city councils immediately implement measures to contain this influx from Antwerp. They requested prohibitive orders for the sale of paintings by foreigners and wanted this laid down in new or revised guild regulations. In this period, the guilds, including that of the painters, were often dormant or no longer existed at all, as was the case in Leiden. All at once, however, steps to protect the local market were taken everywhere.

In November 1608, the Amsterdam guild members complained to the city council that countless paintings from Antwerp and other enemy territories were being sold by foreigners at public auctions and that these paintings were being peddled for much more than their value through "cunning and ungodly importunity," because the "majority [are] poor copies." Stimulated by profit, they contended, these interlopers obtained as many paintings as possible in Antwerp and the surrounding area, "such that a multitude of paintings is presently at [their] disposal, in order to be sold here in the above-mentioned manner." The Amsterdammers were convinced that by 
permitting these "malicious public auctions practiced by strangers, they [their numbers] would increase from day to day and in a short time this city, yea the entire country would be filled with rubbish and inferior apprentices' work." They also feared that the local painters, already so hard hit by the war, would be seriously hindered in earning a living. They added that "the good burgers here, who by and large have little knowledge of painting, [are being] deceived." 33

21 In Leiden, too, the painters called for action. From a petition of March 1610 it appears that they had already submitted a complaint in October 1609 regarding the sellers from "Brabant and surrounding places" who were depriving them of their livelihood. The fact that an immediate ban on sales outside of the annual markets was instituted does not seem to have helped. In 1610 the Leiden painters complained that those same interlopers (who came from Amsterdam to Leiden) simply went about their business, even though they were aware of the ban. They sell paintings "door uytroepen" (by publicly auctioning them), and whatever is left "in open shops [...] as though they lived here." To these indignant words they added that this practice was prohibited in other cities and that the Leiden painters "were grievously injured" by it. Given "these difficult expensive times," they begged the city council for permission to establish a guild, for otherwise they would be unable to provide adequately for their families. ${ }^{34}$

22 Both in Amsterdam and in Leiden a regulation was established barring people from outside the city from either selling paintings themselves or having others sell them on their behalf without the permission of the burgomasters. Evidently, this regulation had little effect because in a new request of 1613, Amsterdam painters complained that those same foreigners still managed to have their paintings auctioned, either by giving them to Amsterdammers as collateral, under the pretext that they could not pay off their debts, or by offering them for sale under the name of a citizen (poorter).$^{35}$ On this occasion it is also stated that burghers are usually deceived by the manner of auctioning, "often buying copies instead of originals." ${ }^{36}$ Moreover, the sellers were said to withdraw the good works when the bids were too low, "such that the country was being filled mostly with copies and other worthless rubbish, occasioning the ridicule of all distinguished art lovers and the noticeable disrepute of art." Poorters were now also required to ask permission before they could auction paintings. A new stipulation followed in 1617: paintings not made within the Seven Provinces could not be sold outside of the annual markets. ${ }^{37}$ Evidently, the undesirable practices involving "Brabant" paintings were still a thorn in the guild members' side.

23 The importation from the south seems to have made an impact elsewhere as well, for between 1609 and 1611 existing guild privileges were tightened up, new ones were instituted, and requests to establish new guilds were submitted in virtually all Dutch towns of any stature, including Gouda (1609), Rotterdam (1609), Delft (1611), and Utrecht (1611)..$^{38}$

24 Clearly, the inundation of the market with cheap paintings caused local artists to fear that their income would be eroded. But what actually happened? Precisely the opposite of what everyone had expected. With the swift growth in the number of painters as well as the number of works a painter produced, the market also embarked on what would be an extraordinary expansion. From the reactions of the Amsterdammers, who, after all, alleged that these sellers - encouraged by the profit they made - did everything in their power to amass whatever paintings they could in Antwerp and surroundings, ${ }^{39}$ it can be seen that the intruders were evidently successful and there 
was no shortage of buyers for the Antwerp imports. Although the guild members cited the inferior quality of the works as the main reason for their concern and capitalized on the customers' fear of buying a copy instead of an original (principaal), in my opinion their real objection (and panic) was that these paintings sold so readily for prices they felt were too high. In other words, they were in great demand - despite the disparaging judgment of the dean and headmen - by a public willing to pay more than they were worth, according to local painters. Most likely the buyers were primarily the Southern Netherlandish immigrants, who were now in a position and ready to purchase these, to them, familiar items.

The question is whether the quality of the imported paintings was, indeed, as inferior as their critics would have us think. They were very inexpensive compared to the paintings that the established painters tended to make, and undoubtedly that was threatening enough. The paintings were probably cheaper because they were made according to different production methods, for example by means of a less time-consuming and labor-intensive technique. And this afforded more than ample reason for labeling them as rubbish, apprentices' work, and copies; this was the most obvious vocabulary for expressing scathing censure. ${ }^{40}$ Moreover, when such works were sold for prices higher than the guild members deemed appropriate on the basis of technical execution and time investment, the traditional way in which they determined prices was entirely overturned. Furthermore, one wonders whether the buyers in fact mostly comprised burghers "who on the whole have little knowledge of paintings" (die door den banck weynich kenisse van schilerye hebben).

26 Examining the accidentally preserved registers of the "voluntary auctions" (willige verkopingen) held under the auspices of the Amsterdam orphanage between 1607 and 1613 (thus in the period of the protests) and which probably incited the fierce response of the dean and headmen of the guild, ${ }^{41}$ a substantial number of inexpensive to very cheap works do appear to have suddenly come onto the market through this channel. At some of these auctions the majority of the paintings sold for trifling amounts - from ten stivers to ten guilders - and this applied to biblical scenes and mythological subjects as well as tronies, still lifes (bouquets and fruit arrangements), kitchen pieces, landscapes, ships, fires, banquets, and peasants. ${ }^{42}$ Only the ubiquitous tronies were consistently cheap. The prices commanded by the other categories - and this pertains particularly to history pieces, landscapes, and kitchen interiors - could rise to over fifty guilders, and in a few instances many times more than that amount. ${ }^{43}$ Accordingly, there were enormous variations in price. This could differ per auction, depending on whether the emphasis was on very cheap or somewhat more expensive work. However, at most of these sales a large to very large number of inexpensive paintings were indeed sold. ${ }^{44}$ Perhaps the biblical and mythological scenes counted many copies, certainly among the innumerable works that went for less than five guilders. However, the multitude of inexpensive landscapes, still lifes, and peasant scenes - specialities developed in Antwerp - could also have been originals (principalen) produced in a fast technique. Insofar as can be determined, many of these paintings did not fall in the lowest price category but fetched between ten and twenty guilders. ${ }^{45}$ An ample number of buyers at these sales appear to have been knowledgeable individuals. The same names are encountered over and over again, especially those of Amsterdammers of Southern Netherlandish - usually Antwerp - origin who were often registered as painters but were presumably primarily active as dealers. ${ }^{46}$ They most likely subsequently sold the works chiefly in their own circle - that is to Southern Netherlandish 
immigrants.

\section{IV}

27 The influx of cheap paintings from Antwerp seems to have functioned as a booster. The buying patterns of immigrants who began decorating the walls of their homes with these inexpensive paintings (the subject and style of which had hardly changed since they had fled) will have invited imitation on the part of indigenous citizens with the same social standing. After all, a large share of the new elite of affluent merchants and trained craftsmen was composed of immigrants. In several respects they also formed a cultural elite, although their culture was frequently mockingly stereotyped. This stereotyping must have derived primarily from a sense of inferiority and jealousy. As Briels described it, the ridicule almost always revolved around the cliché that the naturally sober Dutch were seduced by the finery, ostentation, and vanity introduced by the Brabanders. ${ }^{47}$ The most famous example of such a southerner embodying every stereotype to a ludicrous degree is Jerolimo in Bredero's Spaanschen Brabander: entirely predictably he turns out to have incurred a large debt with a painting dealer. ${ }^{48}$

28 Because a group with equal purchasing power from the indigenous population began to adopt the Southern-Netherlandish custom of surrounding itself with paintings, the demand must have grown further still, while simultaneously - to the extent that this had not already taken place - measures were being instituted in virtually all of the cities to curtail the sale of imported paintings. I suspect that at that moment several established masters began to intensify their production by making less expensive works. ${ }^{49}$ Above all, however, ever more young men, including many children of immigrants, began to fill this hole in the market. Not only did they have to compete with their own masters from the older generation but also and chiefly with the cheap imports from Antwerp, which regardless of the illegal auctions (that were evidently still being held) must also have been available at annual and weekly markets and at kermisses and public sales held outside the city.

29 The best way of fighting the Brabant competition was to take the conventions familiar to this public and deliver a qualitatively better painting that was not that much more expensive. ${ }^{50}$ The subjects of the paintings produced in greatly growing numbers during the second and third decades of the seventeenth century in the cities of Holland thus remained the same as those found in Antwerp inventories and in the aforementioned Amsterdam sales between 1607 and around $1614 .{ }^{51}$ Within this context, the production of landscapes rose the most rapidly.

The question of whether this "process innovation" was set in motion by artistic or economic impulses is irrelevant in my view. ${ }^{52}$ An obvious way of being able to compete in this new market of relatively inexpensive paintings was to supply higher quality - works that were more technically clever, appealing, interesting, and lifelike - while keeping the production costs low. As painters found themselves producing for a relatively broad public, which made its choices at auctions, at the market, or in the shop, artistic and economic rivalry became indelibly linked. As indicated above, to an ambitious young artist in this period, notions of artistic emulation would have been just as self-evident as the need for economic competition. And, given the various gradations of praise that Van Mander, among others, lavished on specialists of all kinds - from Pieter Bruegel and Gillis van Coninxloo, to Jacob Grimmer, Pieter Baltens, Cornelis Molenaer, Hans Bol, and 
David Vinckboons, with emphasis being placed on how highly they were valued by art lovers there could no longer be any doubt that landscapes and peasant scenes also afforded territory for artistic emulation and the opportunity of establishing one's reputation with the art lovers. The latter aspect was also - or perhaps precisely - of importance to painters who did not work on commission because they had to create their own demand. Should one want to be "held in great esteem" (in grooter weerden ghehouden) - which also meant being able to command higher prices - recognition was imperative..$^{53}$

31 Accordingly, a well-trained and ambitious young painter simply had to make his name by producing an identifiable, characteristic product of exceptional quality. He could elect to concentrate on one or more of the, for Holland still relatively new, specialities with which a substantial number of Southern Netherlanders had already found acclaim. In addition, he could try to keep the production costs per painting low by working fast and expanding his output to better counter the competition afforded by the inexpensive Southern Netherlandish painters. Should he succeed in acquiring a good reputation with such paintings, then the profit margins became increasingly greater.

As stated in the beginning, Samuel van Hoogstraten pointed out much later in the seventeenth century that those artists who turned to "ras schilderen" (rapid painting) did this for profit as well as fame..$^{54}$ From this comment, too, we see that economic and artistic preoccupations in this context appear to have been inextricably linked. Therefore, it should come as no surprise that this observation is followed by the mention of Porcellis and Van Goyen, two painters who were exceptionally successful in attaining high artistic standing with swiftly painted works. While their paintings were not expensive, they still commanded relatively high prices proportionate to their scant production costs.

\section{V}

33 Let us now turn our attention to one of the most important innovators in the Northern Netherlands, who in the first decades of the seventeenth century established a formidable reputation as a landscape painter: Esaias van de Velde (1587-1630). He was an immigrant child who began his career in the first years of the Twelve Years' Truce and came from an Amsterdam-Antwerp milieu of painters/dealers. His mother was among those individuals who organized an auction of very inexpensive paintings (she did so shortly after the death of her husband in 1609). ${ }^{55}$ It can be established that even in his earliest works (as of 1614), Esaias already used very thin paint and worked in a swift and straightforward manner (figs. 1-2). ${ }^{56}$ This saved him a lot of time and he could produce a painting incomparably faster than, for example, Gillis van Coninxloo or Roelant Savery, with their detailed, refined, meticulous method involving underpainting and several paint layers. Moreover, Esaias was also capable of painting in a far more elaborate and precise technique, probably when working on a commission, which will have raised the work's price considerably. ${ }^{57}$

34 Since Michael Montias forwarded his pioneering theory that Esaias van de Velde and Jan Porcellis set in motion a process and product innovation that lowered costs and made it possible to work for a broader market, ${ }^{58}$ a process that was later further implemented by Van Goyen and many others, no one seems to have addressed the question of whether these changes in Northern Netherlandish art adopted a process and product innovation that might have been developed 


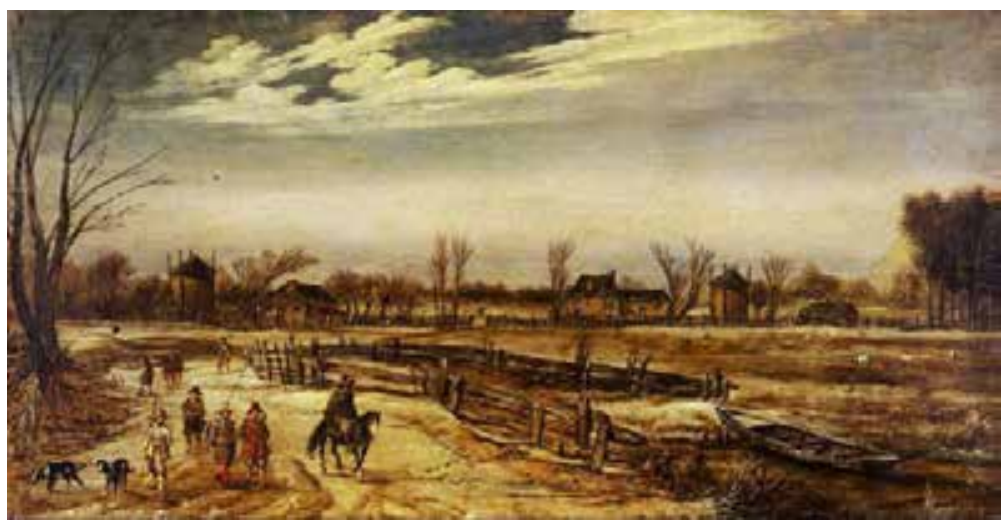

Fig. 1 Esaias van de Velde, Winter Landscape, 1614, oil on panel, 21 x $40.6 \mathrm{~cm}$. Fitzwilliam Museum, Cambridge (artwork in the public domain)

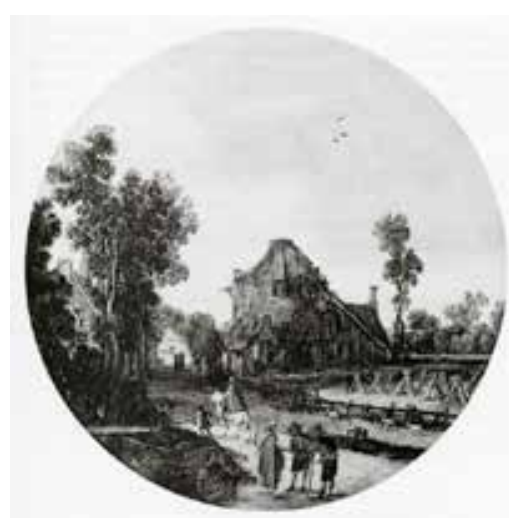

Fig. 2 Esais van de Velde, View of a Village, 1616, oil on panel, diameter $19 \mathrm{~cm}$. Private collection, Germany (artwork in the public domain)

earlier in Antwerp. In his biography of Cornelis Molenaer, called "Schele Neel" (Cross-eyed Neil), a now unknown landscape painter who joined the Antwerp guild in 1564 and died in 1598, Karel van Mander tells us that he was "wonder veerdig," which means that he could paint astonishingly quickly. He continues that Molenaer "worked for very little money on a daily wage" and notes: "He could make a beautiful large landscape in a single day were it prepared somewhat in advance." ${ }^{39}$ Van Mander had already mentioned that his painterly foliage was unsurpassed and that "[other] painters are charmed by everything by him they see." He ends with the remark that his works are "highly valued by the art lovers." Unfortunately, we know of no works securely attributed to this master that would allow us to determine his technique and style. However, mentions of landscapes by this Southern Netherlandish artist are frequently found in Dutch inventories. ${ }^{60}$

35 Hence, here Van Mander describes an Antwerp landscape painter with a fast and inexpensive production technique whose paintings were nevertheless highly appreciated. Another example is Jacob Grimmer (ca. 1525-ca. 1590), by whom numerous simple village views and winterscapes are still known, and who, together with his sons, must have produced many inexpensive landscapes: Van Mander writes that he was "very swift in his work." He praises the naturalness and verisimilitude of Grimmer's work, mentioning that Jacob painted many views around Antwerp and that in so me respects his landscapes were unrivaled, namely "in all things [being] very true-to-life, whether houses, distant landscapes or foregrounds" (fig. 3). ${ }^{61}$

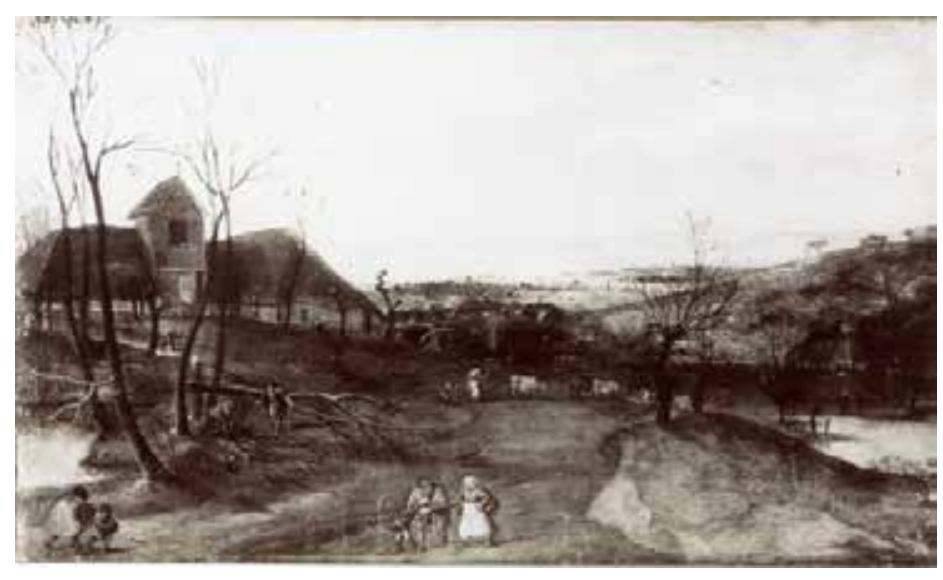

Fig. 3 Jacob Grimmer, Landscape with Peasant Cottages: Autumn (from a series of the four seasons), oil on panel $35.5 \times 59.5 \mathrm{~cm}$. Museum van Schone Kunsten, Budapest (artwork in the public domain) 


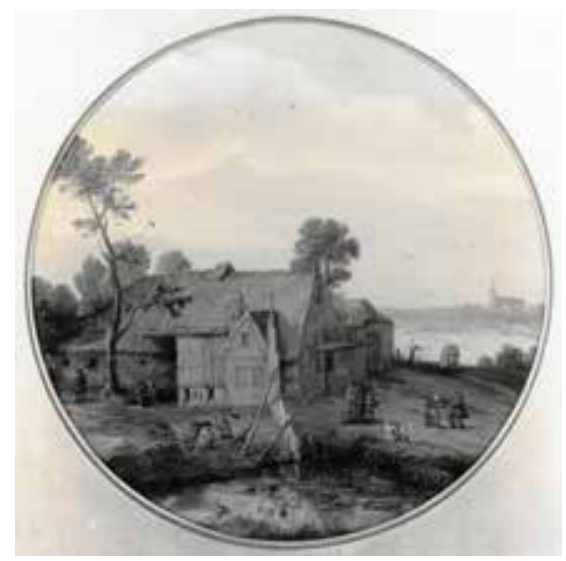

Fig. 4 Pieter Balten, Landscape with Peasant Cottages, 1581 , oil on panel, diameter $23.5 \mathrm{~cm}$. Museum Bredius, The Hague (artwork in the public domain)

36 Van Mander also refers to a "veerdige" (swift) working method in the case of Pieter Balten (ca. 1525-1598?), "a very good landscape painter, closely following the manner of Pieter Brueghel [...] [who] had also visited various countries, and done various views from life. He worked in watercolor and in oil paint, in a lovely and swift manner." In addition to various peasant scenes, only one landscape by Balten is known. Fully signed and dated 1581, it depicts a farmhouse near a body of water, beyond which is a simple flat landscape with a church tower in the distance (fig. 4). This small painting - a perfect example of what we would imagine as an inexpensive roundel costing a few guilders and as found in large numbers in sales and in inventories - could almost be taken for a Dutch painting from circa 1620. It has been cited earlier in the art historical literature to demonstrate the insufficiently acknowledged influence of Flemish artists of this period on the work of Van de Velde. ${ }^{62}$ Unfortunately, it was stolen from the Museum Bredius in The Hague, making a closer analysis of it impossible. Nevertheless, in an excellent transparency of this little panel, one can see how thinly and quickly, and probably partly wet-in-wet, the cottage and the surrounding landscape were painted in various shades of light brown. ${ }^{63}$ Only the figures were applied in stronger colors on the thin paint layer. The type of landscape and the composition also demonstrate how the two print series known as "The Small Landscapes" published by Hieronymus Cock in 1559 and 1561 were followed in such paintings (figs. 5a-c), for this small work fits in

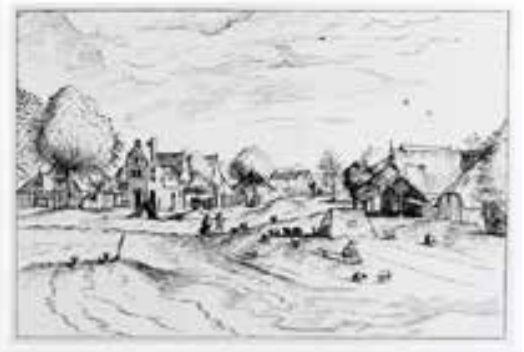

Fig. 5a Johannes and Lucas van Doetecum after the Master of the Small Landscapes, Landscape with View of a Village (from the series Praediorum villiarum [...]), 1561, etching, $29.8 \mathrm{x}$ $20.3 \mathrm{~cm}$. (artwork in the public domain)

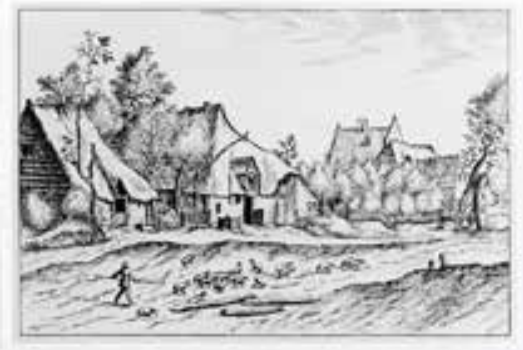

Fig. $5 b$ Johannes and Lucas van Doetecum after the Master of the Small Landscapes, Road by Peasant Cottages (from the series Praediorum villiarum [...]), 1561, etching, $29.8 \times 20.2 \mathrm{~cm}$. (artwork in the public domain)

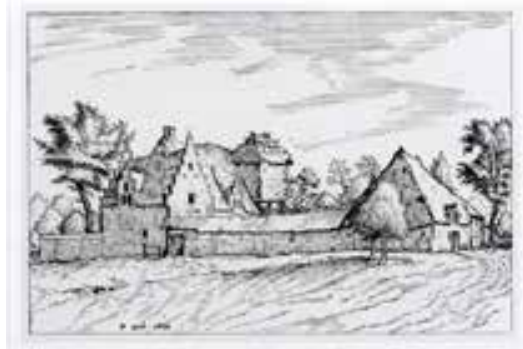

Fig. 5 c Johannes and Lucas van Doetecum after the Master of the Small Landscapes, View of a Farmstead (from the series Praediorum villiarum [...]), 1561, etching, $31.9 \times 20.4 \mathrm{~cm}$. (artwork in the public domain)

seamlessly with the graphic imagery. A technical analysis and a comparison of the painting style of the - usually anonymous - Antwerp landscapes from the late sixteenth century with works by Dutch landscape painters, who renewed the painting process in the second and third decades of 
the seventeenth century, would probably yield fruitful insights. Incidentally, it is clear that the early imaginary landscapes by Joos de Momper - whose work must have been very popular in Amsterdam - while, indeed, underpainted in the traditional three different colored zones indicating fore, middle, and background, were extremely swiftly and masterfully finished in a very thin painting style. ${ }^{64}$

37 While the young Esaias van de Velde, who in the Northern Netherlands turned his attention to the depiction of the native Dutch landscape, was undoubtedly a major innovator, neither his technique nor the motifs came out of the blue. ${ }^{65}$ Both he and his countless Antwerp precursors, from Grimmer and Balten to De Momper and Jan Brueghel, variously emulated compositions by - or from the immediate circle of - the then already exceptionally admired Pieter Bruegel. Esaias van de Velde incorporated motifs familiar from the above-mentioned print series of 1559 and 1561 published by Hieronymus Cock in Antwerp (thirty-two and thirty engravings with two title prints, respectively). The first series is recommended on the first title page as "Many very splendid views [...] rendered from life, and mostly in the vicinity of Antwerp." ${ }^{66}$

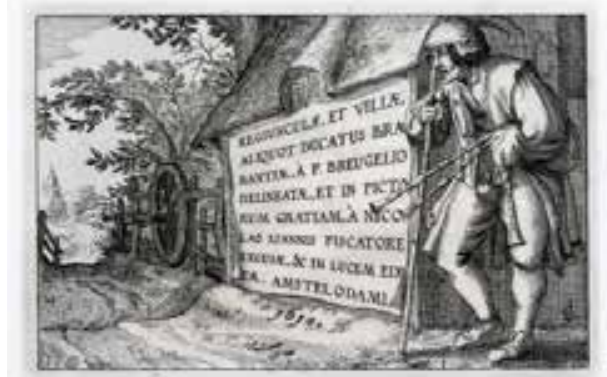

Fig. 6a Claes Janszn Visscher after the Master of the Small Landscapes Title print (from the series Regiuncule, et villae [...]), 1612, etching, $10.4 \times 15.8 \mathrm{~cm}$. (artwork in the public domain)

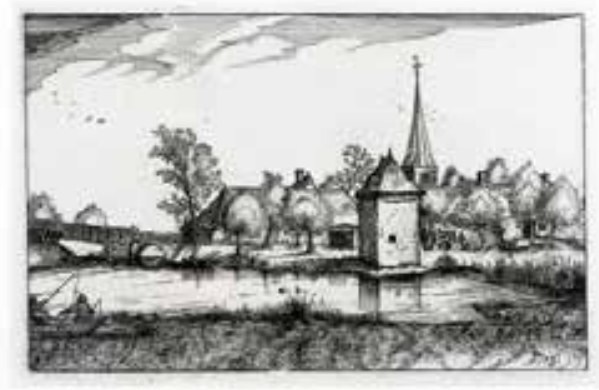

Fig. 6c Claes Janszn Visscher after the Master of the Small Landscapes, View of a Village, with Church Tower (from the series Regiuncule, et villae [...]), 1612, etching, 10.4 × 15.8 $\mathrm{cm}$. (artwork in the public domain)

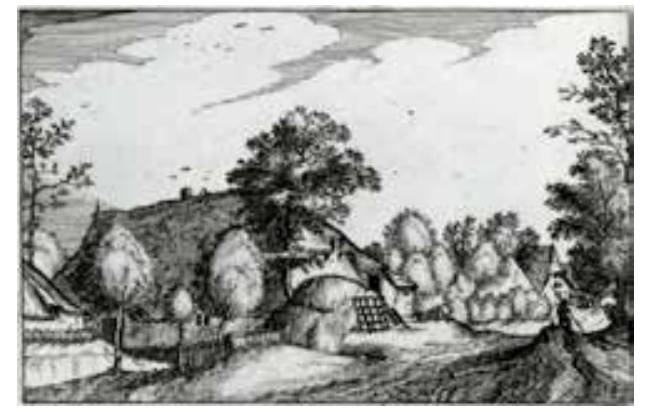

Fig. $6 \mathrm{~b}$ Claes Janszn Visscher after the Master of the Small Landscapes, Road by Peasant Cottages (from the series Regiuncule, et villae [...]), 1612, etching, $10.3 \times 15.8 \mathrm{~cm}$. (artwork in the public domain)

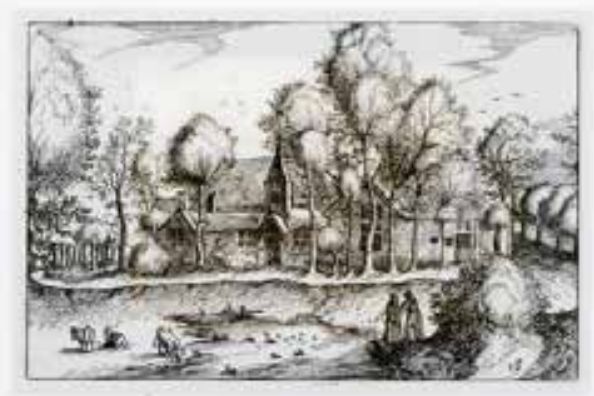

Fig. 6d Claes Janszn Visscher after the Master of the Small Landscapes, View of a Farmstead (from the series Regiuncule, et villae [...), 1612, etching, $10.3 \times 15.9 \mathrm{~cm}$. (artwork in the public domain)

38 That just these prints became so popular at the beginning of the seventeenth century is highly significant. Both series were republished by Theodor Galle in Antwerp in 1610, and a fairly free etched copy of the greater part of the second series was made by the Amsterdammer Claes Janszn. Visscher in 1612 (fig. 6a-d). The title page of the latter publication emphatically states that they 
are Brabant landscapes after Pieter Bruegel (Regiunculae et villae aliquot ducatus Brabantiae à $P$. Breugelio delineatae). ${ }^{67}$ Visscher surely included Bruegel's name as a selling point (and may actually have thought that Bruegel was responsible for the designs). He would have realized that republishing the prints was highly worthwhile because of their appeal to a public homesick for its native country, ${ }^{68}$ and which knew what Bruegel's name stood for. The publication of this series immediately elicited rivalry and countless imitations followed, including those by Esaias and Jan van de Velde. Claes Janszn. Visscher had earlier begun to produce a Dutch pendant to this series, including the four views outside of Amsterdam from circa 1610 (figs. 7a-b) and the famous series of "plaisante plaetsen" near Haarlem from circa 1612-13 (figs. 8a-c). ${ }^{69}$ From this moment on, depictions "after life" of the countryside around the towns where many Brabanders and Flemings had settled for good became exceptionally popular. ${ }^{70}$ The numerous print series from this period include all kinds of motifs that would determine the image of the "Dutch" landscape for the next twenty years in varying combinations.

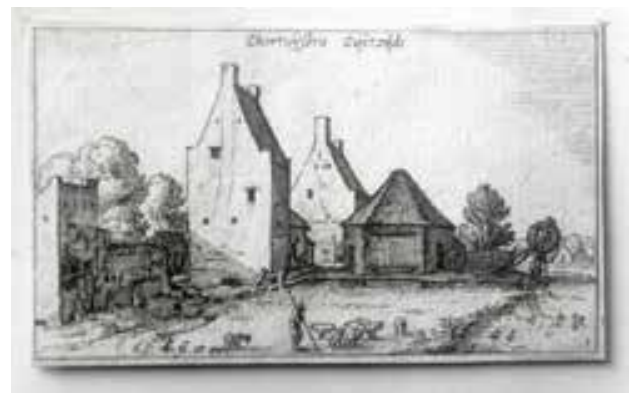

Fig. 7a Claes Janszn Visscher, The Chartreusian Monastery (from the series Four Views outside Amsterdam), ca. 1610, etching, $5.6 \times 9.7 \mathrm{~cm}$. (artwork in the public domain)

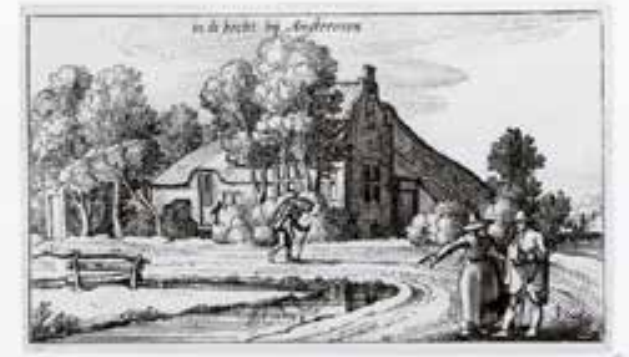

Fig. 7b Claes Janszn Visscher, Amsteldijk by Kostverloren (from the series Four Views outside Amsterdam), ca. 1610, etching, $5.6 \times 9.7 \mathrm{~cm}$. (artwork in the public domain)

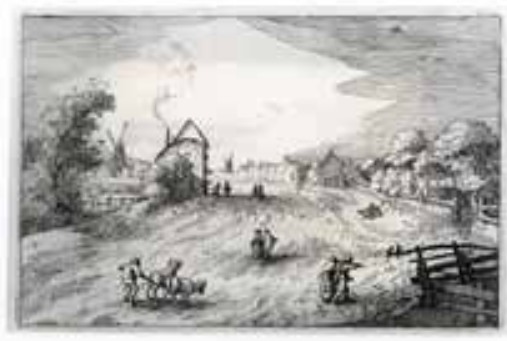

Fig 8a Claes Janszn Visscher, The Road to Leiden (from the series Pleasant Places [...]), ca. 1611-14, etching, $10.3 \times 15.8 \mathrm{~cm}$ (artwork in the public domain)

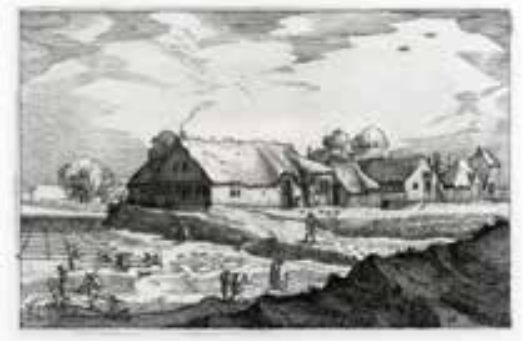

Fig 8b Claes Janszn Visscher, Bleaching Fields by the Haarlemmerhout (from the series Pleasant Places [...]), ca. 1611-14, etching $10.4 \times 15.8 \mathrm{~cm}$ (artwork in the public domain)

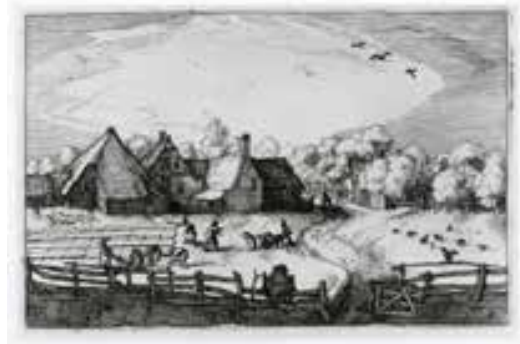

Fig 8c Claes Janszn Visscher, Bleaching Fields by the Dunes (from the series Pleasant Places [...]), ca. 1611-14, etching, $10.3 \times 15.8 \mathrm{~cm}$ (artwork in the public domain)

\section{VI}

39 In many of his early paintings, Esaias van de Velde concentrated on a sober, instantly recognizable type of landscape based on motifs from the print series mentioned above. He did this in extremely simple compositions with only a few figures and objects and, as we have seen, usually in combination with a rapid production technique (figs. 1-2). It has often been assumed that these seemingly unpretentious subjects were also intended for an unpretentious laymen's public. ${ }^{71}$ This seems to me, certainly in its generality, to be a misapprehension. While the relatively low prices, indeed, allowed a far larger public to buy such works, someone like Esaias van de Velde will have 
painted them foremost in the hope of gaining recognition from a fairly "sophisticated" audience of art lovers. One would need some degree of expertise to discern that in such modest landscapes the artist has played in an exquisitely refined manner with conventions that reach back to the by then highly regarded work of Pieter Bruegel and his circle. ${ }^{72}$ One would also require some knowledge to be able to distinguish and appreciate the virtuosity of his technique: the seeming ease, the "sprezzatura" of the facture, and the sophistication of the unassuming composition, which seems to be nonchalantly built up and in which depth is exceptionally convincingly suggested with a minimum of means. ${ }^{73}$ The expert will have been aware that achieving the effect of such great spatial depth in a flat landscape seen from a low vantage point and with a limited palette was very difficult and required greater skill than a traditional mountain or hilly landscape with a high vantage point and contrasting colors. The natural atmosphere of familiar surroundings and the suggestion that this was done entirely "from life" is rendered with unprecedented nonchalance.

Constantijn Huygens, a preeminent connoisseur, would most certainly have recognized such technical brilliance. That he considered being able to assess technical skill as an important aspect of art appreciation can be inferred from his comment that his father - a Brabander by the way believed that one was only qualified to judge paintings (which nowadays one finds everywhere, he adds), if one had learned the rudiments of this art in practice oneself. ${ }^{74}$ Huygens placed great value on the work of Esaias van de Velde. In his account of the art of painting of his time he singled out the Antwerper Jan Wildens and Esaias van de Velde for particular praise from the (according to him) countless number of landscape painters, equating them with the celebrated Paul Bril. ${ }^{75}$ Three painters who made landscapes in entirely different techniques, varying greatly in both style and price range, were thus elevated to the same artistic level. In the preceding line, Huygens had already characterized - in a single breath - the still relatively young Cornelis van Poelenburch, a painter of costly and extraordinarily refined idyllic Italianate landscapes, and Jan van Goyen, the equally young virtuoso of modest Dutch landscapes as particularly famous artists. ${ }^{76}$ Not much later Leiden's burgomaster, Jan Orlers, too, would call Esaias van de Velde the "excellent and renowned landscape painter" and subsequently sing the praises of Van Goyen, saying that his works "were highly valued by all art lovers." Their simple, rapidly executed paintings were greatly appreciated by experts despite the inexpensive production method.

41 The "loose" technique, new for Holland, was highly suited to suggesting naturalness, and this must have been a primary goal of many artists in this period, one about which Huygens, once again, testifies. To be sure, he is not discussing painting when he writes with disapproval about the stiff draftsmanship of Hendrik Hondius, his drawing master, but Huygens's judgment betrays the particular importance he attached to naturalness, which he linked to a fleet, lively technique. Hondius's way of working, he writes, was suited only for the depiction of immobile architecture, and certainly not for the depiction of "free moving things, such as grass, leaves and bushes, or the rendering of the charm that can emanate from ruins in all their shapeless splendour." ${ }^{38}$ That Huygens valued Jan Porcellis's work far above the more detailed and more expensive work of the still active Hendrik Vroom - the most famous marine painter of an older generation - is entirely in keeping in this context. Porcellis had so surpassed Vroom that Huygens wrote he hardly dared mention their names in the same breath. In this case too, the lower prices, related to the more rapid production process, had no bearing on the artistic appreciation of a connoisseur such as Huygens. 
Admiration of virtuosic, loose brushwork in fact was at odds with the indigenous tradition of the "neat" painting technique. When a large number of landscape painters from the next generation, such as Pieter de Molijn, Salomon van Ruysdael, and Jan van Goyen, took up this rapid painting style, there were others of the same age who opted for an "expensive" technique involving finely painted, carefully layered, highly detailed works. A good example of this is the aforementioned Cornelis van Poelenburch, who had successfully developed his innovative type of Arcadian idylls during his sojourn in Italy. The technique he used for this - with painstakingly applied glazes, shining surfaces, transparent bright colors, and exquisitely refined details - would have been perceived there as typically northern. It is striking that precisely these Italianate painters - as was probably expected of them in Italy - cultivated this northern tradition of "neat" painting, a tradition associated with northerners ever since Van Eyck and Lucas van Leyden. ${ }^{79}$

43 Due to the substantial expansion of the art market and the accompanying process and product innovations that had taken place since the beginning of the seventeenth century, young painters - depending on their background, training, ambition, and talent - could choose from far more differing paths than ever before. The impulses generated at the beginning of the century by the inexpensive Antwerp paintings that fairly suddenly flooded the market and the reactions to this on the part of the immigrant public were probably important stimuli for the expansion of this market, as well as for the growth in specialization and the changes in production technique. The rest was subsequently effected by the resulting fashion among burghers of decorating their homes with a profusion of paintings, combined with an increasing prosperity and a consciousness that the Dutch masters were implementing a remarkable achievement, to state it roughly. In the course of the second and third decades of the seventeenth century the production of paintings was intensified and differentiated in keeping with the desires of the burghers to such an extent that one no longer needed to fear the Antwerp market. Giving instructions to her sister Magdalena in 1632, when the latter was on the verge of moving from Antwerp to Amsterdam (Magdalena had lived in Italy for twelve years and was apparently not entirely au courant about the situation), Elizabeth Stockmans wrote that it was entirely unnecessary to buy paintings in Antwerp, for "paintings are also available here in great numbers. Some of the best masters live here presently."

\section{Acknowledgements}

The author would like to express particular gratitude to Neil De Marchi. After my presentation of an earlier version of this paper at the conference Art for the Market (Middelburg, December 10-12, 1998), I had several fruitful discussions with him about this subject. I am also grateful to Marion Boers-Goosens who allowed me to use data from the research for her dissertation "Schilders en de markt: Haarlem 1600-1635" (PhD diss., Leiden University, 2001).

Eric Jan Sluijter is professor of Early Modern Art at the University of Amsterdam. Previously he taught at Leiden University and, at the beginning of his career, worked as research fellow at the Rijksbureau voor Kunsthistorische Documentatie. He was visiting professor at Yale University (1991) and Università di Roma 'La Sapienza' (1993) and from 2002 till 2007 at the Institute of Fine Arts, New York University. Presently he directs the research program (funded by NW0): Artistic and Economic Competition in the Amsterdam Art Market (1630-1690): History Painting in Amsterdam in Rembrandt's Time. His most recent book: Rembrandt and the Female Nude (Amsterdam 2006). 


\section{List of Illustrations}

Fig. 1 Esaias van de Velde, Winter Landscape, 1614, oil on panel, 21 x $40.6 \mathrm{~cm}$. Fitzwilliam Museum, Cambridge (artwork in the public domain)

Fig. 2 Esais van de Velde, View of a Village, 1616, oil on panel, diameter $19 \mathrm{~cm}$. Private collection, Germany (artwork in the public domain)

Fig. 3 Jacob Grimmer, Landscape with Peasant Cottages: Autumn (from a series of the four seasons), oil on panel $35.5 \times 59.5 \mathrm{~cm}$. Museum van Schone Kunsten, Budapest (artwork in the public domain)

Fig. 4 Pieter Balten, Landscape with Peasant Cottages, 1581, oil on panel, diameter $23.5 \mathrm{~cm}$. Museum Bredius, The Hague (artwork in the public domain)

Fig. 5a Johannes and Lucas van Doetecum after the Master of the Small Landscapes, Landscape with View of a Village (from the series Praediorum villiarum [...]), 1561, etching, $29.8 \times 20.3 \mathrm{~cm}$. (artwork in the public domain)

Fig. 5b Johannes and Lucas van Doetecum after the Master of the Small Landscapes, Road by Peasant Cottages (from the series Praediorum villiarum [...]), 1561, etching, $29.8 \times 20.2 \mathrm{~cm}$. (artwork in the public domain)

Fig. 5c Johannes and Lucas van Doetecum after the Master of the Small Landscapes, View of a Farmstead (from the series Praediorum villiarum [...]), 1561, etching, 31.9 x $20.4 \mathrm{~cm}$. (artwork in the public domain)

Fig. 6a Claes Janszn Visscher after the Master of the Small Landscapes Title print (from the series Regiuncule, et villae [...), 1612, etching, 10.4 x $15.8 \mathrm{~cm}$. (artwork in the public domain)

Fig. 6b Claes Janszn Visscher after the Master of the Small Landscapes, Road by Peasant Cottages (from the series Regiuncule, et villae [...]), 1612, etching, $10.3 \times 15.8 \mathrm{~cm}$. (artwork in the public domain)

Fig. 6c Claes Janszn Visscher after the Master of the Small Landscapes, View of a Village, with Church Tower (from the series Regiuncule, et villae [...]), 1612, etching, 10.4 x $15.8 \mathrm{~cm}$. (artwork in the public domain)

Fig. 6d Claes Janszn Visscher after the Master of the Small Landscapes, View of a Farmstead (from the series Regiuncule, et villae [...]), 1612, etching, $10.3 \times 15.9 \mathrm{~cm}$. (artwork in the public domain)

Fig. 7a Claes Janszn Visscher, The Chartreusian Monastery (from the series Four Views outside Amsterdam), ca. 1610, etching, $5.6 \times 9.7 \mathrm{~cm}$. (artwork in the public domain)

Fig. 7b Claes Janszn Visscher, Amsteldijk by Kostverloren (from the series Four Views outside Amsterdam), ca. 1610, etching, $5.6 \times 9.7 \mathrm{~cm}$. (artwork in the public domain) 
Fig 8a Claes Janszn Visscher, The Road to Leiden (from the series Pleasant Places [...]), ca. 161114, etching, $10.3 \times 15.8 \mathrm{~cm}$ (artwork in the public domain)

Fig 8b Claes Janszn Visscher, Bleaching Fields by the Haarlemmerhout (from the series Pleasant Places [...]), ca. 1611-14, etching $10.4 \times 15.8 \mathrm{~cm}$ (artwork in the public domain)

Fig 8c Claes Janszn Visscher, Bleaching Fields by the Dunes (from the series Pleasant Places [...]), ca. 1611-14, etching, $10.3 \times 15.8 \mathrm{~cm}$ (artwork in the public domain)

${ }^{1}$ Samuel van Hoogstraten, Inleyding tot de hooge schoole der schilderkonst (Rotterdam: Francois van Hoogstraeten, 1678), 237: "In 't begin deezer eeuw waeren de wanden in Holland noch zoo dicht niet met Schilderyen behangen, alsze tans wel zijn. Echter kroop dit gebruik dagelijx meer en meer in, 't welk zommige Schilders dapper aenporde om zich tot ras schilderen te gewennen, jae om alle daeg een stuck, 't zij kleyn of groot te vervaardigen.”

${ }^{2}$ About the spectacular increase in the number of paintings produced, see Jan de Vries, "Art History," in Art in History: History in Art, ed. David Freedberg and Jan de Vries (Santa Monica, Calif.: Getty Center for the History of Art and the Humanities, 1991), 249-82. According to De Vries's calculations, the number of active painters would have quadrupled between 1600 and 1620 (p. 273). See also Marten Jan Bok, Vraag en aanbod op de Nederlandse kunstmarkt, 15801700, (PhD diss., Utrecht University, 1994); John Michael Montias, Artists and Artisans in Delft: A Socio-economic Study of the Seventeenth Century, (Princeton: Princeton University Press, 1982), 263-64; John Michael Montias, "Art Dealers in the Seventeenth-century Netherlands," Simiolus 18 (1988): 244-53, esp. 245; and John Michael Montias, Le marché de l'art aux Pays-Bas, XVe-XVIIe siècles, (Paris: Flammarion, 1996), 93-100. About the increase in the possession of paintings, see Montias, Le marché, 71-72; and C. Willemijn Fock, "Kunstbezit in Leiden in de zeventiende eeuw," in Het Rapenburg: Geschiedenis van een Leidse gracht, ed. Th. H. Lunsingh Scheurleer et al. (Leiden: Afdeling Geschidenis van de Kunstnijverheid Rjkuniversiteit, 1990), vol. 5a, 3-36, esp. 5-6.

${ }^{3}$ Peter Mundy, The Travels of Peter Mundy in Europe and Asia, 1608-1667, vol. 4, Travels in Europe, 1639-47, ed. R. Carnac Temple (Cambridge: Hakluyt Society, 1925).

${ }^{4}$ Quoted in Wilhelm Martin, Het leven en de werken van Gerrit Dou beschouwd met het schildersleven van zijn tijd (Leiden: S. C. van Doesburgh, 1901), 95-96.

${ }^{5}$ About the stereotyping of seventeenth-century Dutchmen in general, see Marijke Meijer Drees, Andere landen, andere mensen: De beeldvorming van Holland versus Spanje en Engeland omstreeks 1650, (The Hague: SDU, 1997).

${ }^{6}$ Dirck Raphaelsz. Camphuyzen, Stichtelycke rymen (Amsterdam, 1624) (quoted from the 1642 edition, p. 212); the quoted lines respectively: "'t Malen! ey, wie kan dat wraken sonder al-gemeyn op-roer?"; "Van Graveren, trecken, malen hangt de heele Wer 'lt aen een"; "'t Malen is 't gewoone lockaes voor ' $t$ verseeuwerd hert vol keurs, / Dat in spijt van noodts behoeven ' $t$ gelt ontgoochelt uit den beurs, / 't Malen schijnt de saus van alles wat uyt menschen hersens spruyt."

${ }^{7}$ A. H. Kan, trans., De jeugd van Constantijn Huygens door hemzelf beschreven (Rotterdam: A. 
Donker, 1971), 66. Chris L. Heesakkers, trans., Constantijn Huygens: Mijn jeugd (Amsterdam: Querido, 1987), 72.

${ }^{8}$ It is interesting that Huygens first praises the landscape painters and only then writes that the history painters of the Netherlands are no less talented. Kan, De jeugd, 73; and Heesakkers, Mijn jeugd, 78-79.

${ }^{9}$ Ludovico Guicciardini, Descrittione di tutti paesi bassi (Antwerp, 1567), 97-100; a Dutch translation was published in 1612 (after earlier German and French translations). In his first sentence, Guicciardini sets the tone for the following one and a half centuries: "Since the art of making paintings is an excellent thing when it comes to profit and honour - not only in Antwerp and Mechelen is this craft of great importance, but also in the Netherlands as a whole - it seems to me fitting to mention here several of those in this country who have most given fame to the art by their inventions, of whom some are still alive and some have died" (Maer angehsien de conste der schilderyen een treffelijcken saecke is aengaende profijt ende eere, niet alleenlijck te Antwerpen ende te Mechelen, daer het een ambacht is seer groot van waerden, maar oock de gantsche Nederlanden door: soo dunckt my behoorlijck ende betaemlijck te wesen, hier ettelijcke te noemen vande ghene die in dese landen de conste meest hebben verbreyt ende verciert, waer af sommighe noch leeven ende somnmighe overleeden sijn). Ludovico Guicciardini, Beschrijvinghe van alle de Nederlanden (Amsterdam, 1612), 79. Hadrianus Junius, who wrote his book during the years 1565-70, begins his section on painters with the sentence: "Cognata literis res est Pictura, quae ars ut nobilis, Regibusque expetita, ita olim etiam in primum liberalium gradum recepta, \& quos posteris tradere dignatur, nobilitans. In ea habet Batavia florentia aliqout ingenia, quae neque possum, neque debeo silentio praeterire." Hadrianus Junius, Batavia (Leiden, 1588), 234-40. ${ }^{10}$ Karel van Mander, Het leven der doorluchtighe Nederlantsche, en Hoogduytsche schilders, in Idem, Het schilder-boeck (Haarlem, 1604). The print series mentioned are Pictorum aliquot celebrium germaniae inferioris effigies, Hieronymus Cock (Antwerp, 1572) (four editions through 1600, the last one published by Theodoor Galle with the title Illustrium quos belgium habuit pictorum effigies), and Pictorum aliquot celebrium praecipue Germaniae inferioris effigies, Hendrick Hondius (The Hague, 1610). Concerning these series, see Hans-Joachim Raupp, Untersuchungen zu Künstlerbildnis und Künstlerdarstellung in den Niederlanden im 17. Jahrhundert (Hildesheim and New York: Olms, 1984), 18-45.

${ }^{11}$ For Scribanius's text, with translation and commentary, see Julius S. Held, "Carolus Scribanius's Observations on Art in Antwerp," Journal of the Warburg and Courtauld Institutes 59 (1996): 174-204. Competition with painters from antiquity (and also with the Italians) is of central importance for Scribanius; almost all Antwerp painters discussed are compared with painters from antiquity whom they have supposedly surpassed. doi:10.2307/751403

${ }^{12}$ In most city descriptions the painters are, apart from the learned men, the only group of "famous sons" included. J. Pontanus, Rerum et urbis Amstelodamensium Historiae (Amsterdam: Hondius, 1611); the Dutch edition was published three years later: Historische beschryvinghe der seer wijt beroemde coop-stadt Amsterdam (Amsterdam, 1614), 79-81 (Pontanus was a brother of the painter Pieter Isaacsz). Jan Orlers, Beschrijvinge der stad Leyden (Leiden, 1614), 259-76; second edition 1641, 352-80. Samuel Ampzing, Beschryvinge ende lof der stad Haerlem in Holland (Haarlem, 1628), 345-76. Theodoor Schrevelius, Harlemias, ofte, om beter te seggen, de eerste stichtinghe der stadt Haerlem (Haarlem, 1648), 359-91.

${ }^{13}$ Schrevelius, Harlemias, 359: "It is nowadays still well known that for several centuries the very best painters have been raised in this city" (Ende dit is noch ten huydighe daghe by yder een 
bekent, dat d"alderbeste schilders voor eenige hondert iaren herwaarts, hier op gequeeckt zijn); Simon van Leeuwen, Korte Besgryving van het Lugdunum Batavorum, nu Leyden (Leiden, 1672), 188: "in this city the most famous painters and draughtsman of the whole country were born and raised” (zijn binnen dese Stad geboren, ende opgekweekt, de vermaarste Schilders ende Teyckenaars van het gantsche Land).

${ }^{14}$ Held, "Carolus Scribanius," 179, 192, 201, 203-4.

${ }^{15}$ Ampzing, Beschryvinge, 345. See the excellent article by Huigen Leeflang, "Dutch Landscape: The Urban View; Haarlem and Its Environs in Literature and Art, 15th-17th Century," Natuur en landschap in de nederlandse kunst 1500-1850, Nederlands Kunsthistorisch Jaarboek 48 (1997): 53-115, esp. 80-84.

${ }^{16}$ Kan, De jegud, 68; and Heesakkers, Mijn jeugd, 74.

${ }^{17}$ For instance: De Gheyn (in his capacity as an engraver) vs Goltzius (69), Hoefnagels (in his capacity as a miniaturist) vs Oliver (69), Hoefnagels (in his capacity as a painter of flowers) vs Jan Breughel I and Bosschaert (70), De Gheyn challenging Torrentius (83-84); Goltzius vs Dürer and Lucas (72), Porcellis vs Vroom (72), Rubens vs the Italians in general (74), Van Mierevelt vs Ravesteyn (76), and finally Rembrandt, who surpasses all painters from Italy and antiquity (79). ${ }^{18}$ For instance, see Fock, "Kunstbezit in Leiden," 5.

${ }^{19}$ In her dissertation Marion Boers-Goosens calculated on the basis of a variety of sources the number of painters active in Haarlem in the first decades: in 1605 there were seventeen painters within a population of 30,000 (works of ten painters are still known); in 1615 the number increased to thirty-six (we know works by twenty of those) out of 35,000; in 1625 there were fifty-four painters (works are still known by forty-five of those artists) out of 40,000 inhabitants. Finally, she calculated ninety painters active in Haarlem in 1635; of those at least seventy-nine were artist-painters (population ca. 42,000).Added 2008: See Marion E. W. Goosens, Schilders en de markt: Haarlem 1600-1635 (PhD diss., Leiden University, 2001).

${ }^{20}$ See Montias, Le marché, 99.

${ }^{21}$ In particular, see Bok, "Vraag en aanbod," 95-96 and chapter 4, passim.

${ }^{22}$ Thera Wijsenbeek-Olthuis, Het Lange Voorhout: Monumenten, mensen en macht (Zwolle and The Hague: Waanders, 1998), 82-86. She concludes that ownership of tapestries depended not so much on wealth as on social background. Even the less wealthy nobility owned tapestries, while rich burghers bought larger numbers of paintings.

${ }^{23}$ With the nobility Wijsenbeek-Olthuis counted an average of 25 portraits and 17 paintings of other subjects; with the wealthy magistrates of The Hague, there was an average of 8 portraits and 33 paintings of other subjects. The well-to-do middle class shows a proportion of 3 portraits to 29 paintings of other subjects (based on 60 inventories, 20 for each group). Wijsenbeek-Olthuis, Lange Voorhout, 92-102.

${ }^{24}$ Especially De Vries, "Art History," 265: "the circumstances of the late sixteenth century enlarged the supply of painters by setting in motion a massive migration from Flanders to Holland; these circumstances increased the demand for paintings by establishing a cultural environment that converted art from a 'public good' (provided by state and church) to a 'private good' (acquired by individuals)." See also Bok, "Vraag en aanbod," 97-98; Montias, Artists and Artisans, 73; and John Michael Montias, "Cost and Value in Seventeenth-century Dutch Art," Art History 10 (1987): 455-66, esp. 459. See also Josua Bruyn, "A Turning Point in the History of Dutch Art," in Dawn of the Golden Age: Northern Netherlandish Art 1580-1620, ed. Ger Luijten et al., exh. cat. (Amsterdam, Rijksmuseum, 1993), 112-21, esp. 119. 
${ }^{25}$ J. G. C. A. Briels, Vlaamse schilders in de Noordelijke Nederlanden in het begin van de gouden eeuw, 1585-1630 (Antwerp and Haarlem: Becht, 1987) and Briels, Vlaamse schilders en de dageraad van Hollands gouden eeuw, 1585-1630 (Antwerp: Mercatorfonds, 1998).

${ }^{26}$ J. G. C. A. Briels, De zuidnederlandse immigratie in Amsterdam en Haarlem omstreeks 15721630 (PhD diss., Utrecht University, 1976) and Briels, Zuid-Nederlanders in de republiek, 15721630 (St. Niklaas: Danthe, 1985).

${ }^{27}$ Marion Boers-Goosens concluded that this was very striking in Haarlem: between 1600 and 1605, the number of painters from the Southern Netherlands was still small (four out of nineteen) and was in terms of percentage not to be compared with other crafts (also see the following note). Of the large number of painters Briels mentions in Amsterdam - men who were entered as "painter" in documents, mostly when marrying - we know with certainty only a few that indeed worked as artist-painters; no works are known for most of them (Briels, "De zuidnederlandse immigratie," 79-102; see also the biographies in Briels, Vlaamse schilders, 293-411). It is remarkable that of the living painters discussed by Van Mander, very few were immigrants from the Southern Netherlands (only Badens, Coninxloo, Vinckboons, and De Gheyn, and earlier, in the life of Hans Bol, he mentions Roelant and Jacques Savery). In his discussion of the older generation, by contrast, most of the painters were from the Southern Netherlands. The reason for this is certainly not that he ignored painters who specialized in specific genres, since he does discuss a large number of such painters from the older generation (such as Pieter Baltens, Hans Bol, Jacob Grimmer, Joos van Liere, Claes Molenaer, Gillis Mostart, the brothers Valckenborch, and Hendrick van Steenwijck, all of them working in the Southern Netherlands). Of the living painters Van Mander lists at the end of his account, only three out of fifteen have a Southern Netherlandish background: Cornelis van der Voort and Bernaert and Pouwels van Someren).

${ }^{28}$ In the case of Haarlem, I rely on the data of Marion Boers-Goosens (Goosens, "Schilders en de markt"). For the increase of the number of painters in Amsterdam, see Bok, "Vraag en aanbod," 99-104. Little can be said about Leiden painters; further research is needed. Added 2008: Piet Bakker (University of Amsterdam) is presently working on the Leiden art market.

${ }^{29}$ According to the data of Marion Boers-Goosens, out of the nine painters in 1615 who had started their career after 1605 - they all began between 1610 and 1613 - eight had a Southern Netherlandish background. It is striking that, as of this moment, the data mostly concerns names that are still well known to us.

${ }^{30}$ The inventories published by Duverger start only in 1600, but from these inventories - drawn up during the first ten years of the seventeenth century and the art works of which must have been assembled during the last decades of the sixteenth century - one gets a good impression of the nature and the number of paintings in such estates. E. Duverger, Antwerpse kunstinventarissen uit de zeventiende eeuw, Letteren en Schone Kunsten van België1 (Brussels: Koninklijke Academie voor Wetenschappen, 1984).

${ }^{31}$ See Briels, "De zuidnederlandse immigratie," 52-53. Briels also mentions an interesting letter of 1608 from a French envoy who, responding to the obvious fear that many merchants and craftsmen from the Southern Netherlands would leave during the truce, wrote that this did not seem likely considering the freedom and the security they enjoyed in the republic. See also notes 68 and 70 below.

${ }^{32}$ See the second petition of the Amsterdam dean and masters of the guild (D. O. Obreen, Archief van de Nederlandsche Kunstgeschiedenis [Rotterdam: Van Hengel and Eeltjes, 1880-81], vol. 3, 166-67). It is clear from this document that the paintings were auctioned by the use of "mijnen" 
(also called the "Dutch manner": while the auctioneer called out descending prices, the buyer had to call "mine" at the price he was willing to pay). The petition states that it was unusual to sell goods in this way; it was current to do so only with sales of estates and further that "to auction art in this way [by "mijnen"] is detrimental to all good citizens and had never been in use; no commodities are ever sold in this way as well, except for estates"(de voorsz. maniere [het "mijnen"] van Const opveylinge allen goeden Ingesetenen deser Stede schadelyck, ende noyt in sulcke voegen in swanck is geweest, gemerckt oock geen Coopmanschappen hier ter Stede gewoon syn in sodanigen manieren vercoft te worden, als alleenlycken in erffhuysen). For three variants of the so-called Dutch way of selling by auction, see Neil De Marchi, "The Role of Dutch Auctions and Lotteries in Shaping the Art Market(s) of 17th century Holland," Journal of Economic Behavior and Organization 28 (1995): 203-21, esp. 209. doi:10.1016/0167-2681(95)00032-1. See also doi:10.2307/3046038. It is impossible to say which of the three methods was used in this instance. (Such methods are still in use with auctions of flowers, houses, and estates.)

${ }^{33}$ Obreen, Archief, vol. 3, 164-65. Quoted passages: "door listich ende ongodlyck opdringen"; "zulcx datter een groote menichte Schilderyen tegenwoordich by haerluyden voorhanden is, omme mede alhier in manier als vooren vercoft te worden"; "gepractiseerde malitieuse openbaare opveylingen van Vreemdelingen die van daghe to daghe souden toenemen, in corten tyt dese Stede, jae het geheele Landt met vodden ende slechte leerkinderen werck, souden worden vervult"; "de goede burgerye alhier, die door den banck weynich kenisse van schilerye hebben, bedrogen [wordt])."

${ }^{34}$ J. C. Rammelman Elsevier, "Iets over de Leidsche schilders van 1610, in verband met het geslacht der Elsevieren," Berigten van het historisch gezelschap te Utrecht 1, no. 2 (1846-48): 35-45, esp. 36-37. The painters did not get permission to establish a guild and first had to demonstrate what was usual in other cities. They presented the petition from Amsterdam quoted above, and the decision of the aldermen of Amsterdam, as well as a declaration from Delft, saying that since time immemorial only members of the guild of St. Luke were allowed to sell paintings, except at the annual fairs and weekly markets. However, they only received a regulation for one year in which it was stipulated that, apart from the annual fairs, only the burghers of Leiden were allowed to sell paintings without special permission of the burgomasters (the same regulation as in Amsterdam). A master's thesis by Ed Romein discusses the exceptional situation in Leiden, where the painters received (partial) permission to establish a guild only in 1648. Added in 2008: part of this thesis has been published; Ed Romein, "Knollen en citroenen op de Leidse kunstmarkt: over de rol van kwalitiet in de opkomst van de Leidse fijnschilderstijl," De Zeventiende Eeuw 17 (2001): 75-95.

${ }^{35}$ Obreen, Archief, vol. 3, 166-67.

${ }^{36}$ Ibid: "dickwils copyen voor principalen copende." This document also mentioned that the paintings were auctioned by way of "mijnen"; see note 32 above.

${ }^{37}$ Statute of January 1, 1617, mentioned by I. H. van Eeghen, "Het Amsterdamse Sint Lucasgilde in de zeventiende eeuw," Jaarboek van het genootschap Amstelodamum 61 (1969): 65-102, esp. 90. Quoted passage: "sulcx dat het land hier meestendeel, met copyen ende andere slechte vodden wert gevult, tot spot van alle fraye liefhebbers ende merckelycke disreputatie van de Const." In 1623, a new statute was issued with heavier fines, and in 1626 it was extended again with a regulation that one could only sell by auction in the houses of the sellers, or in the house of the warden, while a memorandum of all the paintings to be sold had to be submitted to the aldermen before the sale. 
${ }^{38}$ G. J. Hoogewerff, De geschiedenis van de St. Lucasgilden in Nederland (Amsterdam: P. N. van Kampen, 1947), 103, 162; Montias, Artists and Artisans, 71-73; and Hessel Miedema, "Kunstschilders, gilde en academie. Over het probleem van de emancipatie van de kunstschilders in de Noordelijke Nederlanden van de zestiende en zeventiende eeuw," Oud Holland 101 (1987): 1-30, esp. 4. In Gouda, the petition of the glass painters and glassmakers had only partial success: the latter group alone was allowed a guild. It is remarkable that we do not hear of anything in Haarlem during this period. Were the old statutes still functioning satisfactorily, or were the painters less concerned about such auction sales? In a document of 1590 it was decreed that a non-guildmember could not sell paintings, except at annual fairs and weekly markets: in practice then, it was possible to sell one's paintings every week. See Hessel Miedema, De archiefbescheiden van het St. Lukasgilde te Haarlem (Alphen aan den Rijn: Canaletto,1980), vol. 1, 59-60. For the controversy in Haarlem concerning auction sales in a later period, see Marion Boers [-Goosens], "Een nieuwe markt voor kunst. De expansie van de Haarlemse schilderijenmarkt in de eerste heflt van de zeventiende eeuw," Nederlands Kunsthistorisch Jaarboek 50 (1999): 195-220.

${ }^{39}$ Obreen, Archief, vol. 3, 165: "those salesmen, beginning to enjoy the profit, and for that reason endeavouring to continue this trade, try to assemble all the paintings they can get their hands on, in Antwerp as well as elsewhere in those regions" (voorsz. vercoopers nu aent profyt beginnende te verleckeren, ende oversulcx soeckende desen handel te continueren, met alle vlyt pogen zoo tot Antwerpen als elders in dien contryen, by een te raepen, al den Schilderyen die zyluyden kennen becomen).

${ }^{40}$ De Marchi, “The Role of Dutch Auctions," 206-12, took this literally and assumed that it concerned indeed rubbish, copies, and works of pupils. For that reason he applied Akerlof's theory concerning the fear of "lemons" (a term from the trade in second-hand cars). However, apart from the fact that the market did not collapse but started to grow rapidly, the success of the auction sales and the probable expertise of the buyers (that is to say, the buyers at the sales mentioned below - we do not know if there were other illegal sales) point in another direction. For the problems concerning originals ("principalen"), copies, and the assessment of quality and value, see Neil de Marchi and Hans J. van Miegroet, "Pricing Invention: "Originals," "Copies," and Their Relative Value in Seventeenth-century Netherlandish Art Markets," in Economics of the Arts: Selected Essays, ed. V. A. Ginsburgh and P.-M. Menge (Amsterdam andOxford: Elsevier 1996), 27-70.

${ }^{41}$ Only the collector of the orphans chamber (for estates and voluntary sales ["willige verkopingen"]) and the warden of the town hall (for "executoriale verkopingen") were allowed to conduct auction sales. Records of the "estates" organized by the orphans chamber have been preserved with some smaller and larger lacune for the period 1587-1638 (twenty-nine volumes). Besides that, one volume has been preserved of the "willige verkopingen" and that concerns the period 22/7/1608 to 3/6/1610 (WA 5073/966). Van Eeghen listed in a footnote (see Van Eeghen, "Het Amsterdamse St. Lucasgilde," 85-86) all the sales with numerous paintings. The sales of estates start with that of Gillis van Coninxloo in 1607, and among the sales of the "willige verkopingen" we find a few large sales in 1608, 1609, and 1610. Van Eeghen assumes that two sales in the fall of 1608 provoked the petition of the dean and aldermen of the guild of St. Luke that followed shortly after (ibid., 89). The petition concerns auction sales requested by Johanna Artsen and Jacques van der Lamen, both from Antwerp and not citizens of Amsterdam (30/9/1608; ca. 69 paintings), and one requested three days later by Felix van Lun, who was also from Antwerp and not an Amsterdam citizen (2/10/1608; 85 paintings). Three weeks later, on October 29, 1608, and again in May 
1609 , there were sales at the request of Valerius van der Houven, described as a painter born in Antwerp (he was an Amsterdam citizen; 20 and 42 paintings respectively). On February 23, 1609, a sale (ca. 148 paintings) was organized by the widow of the recently deceased Hans van de Velde, the father of the painter Esaias van de Velde; Hans was also recorded as a painter and came from Antwerp. In March 1610 there was a sale requested by the painter Lucas Luce, born in Antwerp but an Amsterdam citizen as well (16/3/1610; ca. 140 paintings).

It is probable that these sales (and this might also be the case with the sale of Pieter Loduwijcxs $(23 / 2 / 1609$, ca. 120 paintings) are the kind of sales referred to in the petition of 1613 , in which it is mentioned that non-citizens have paintings sold by auction through citizens. In this period, the sales of estates do not always seem to have been what they were supposed to be. For instance, in 1607, an auction sale was held that was certainly not an estate; it included paintings by, among others, Crispiaen Colyn, Hans van Coninxloo, Barend van Someren, and Pouwels [Vredeman] de Vries - all of them painter/dealers with a Southern Netherlandish background (partly published in A. Bredius, Künstlerinventare (The Hague: M. Nijhoff, 1919), vol. 6, 2051-52). The huge sale of Crispiaen Colyn in 1612 (ca. 620 paintings [!], apart from prints and plaster casts) does not qualify as an estate sale either, as Colyn died in 1618 (published in Bredius, Künstlerinventare, vol. $3,1067-86$ ). This is true as well for the sale of the painter Cornelis van der Voort of 1614 (Van der Voort died in 1625), also Southern Netherlandish by birth (published in Bredius, Künstlerinventare, vol. $4,1173-77)$. In the case of the sale of Claes Rauwert (26/8/1612) one may also wonder if the paintings (ca. 430!) are all from his estate. Further research is necessary. For three auction sales of a somewhat later period, see J. M. Montias, "Trois ventes de tableaux aux enchères à Amsterdam vers 1620," in Curiosité: Etudes d'histoire de l'art en l'honneur d'Antoine Schnapper, ed. O. Bonfait et al. (Paris: Flammarion, 1998), 285-95. Montias researched the buyers at those sales during the whole period for which records are preserved. At the 1999 CAA annual convention he gave a lecture about this research: "Auction Sales in Amsterdam 1597-1638." (I am grateful for having been able to consult a manuscript of this lecture.) Added in 2008: Montias's research has been published in J. M. Montias, Art at Auction in 17th Century Amsterdam (Amsterdam: Amsterdam University Press, 2002).

${ }^{42}$ In most of the sale records subjects are rarely mentioned; they are generally described as " 1 piece of painting" ("1 stuck schilderij") and indicated with a number or character. Only now and then is the name of a painter mentioned. An exception is the fascinating sale of Crispiaen Colyn in 1612 - by far the largest one, but with the lowest prices - in which all the paintings are indicated with a subject.

${ }^{43}$ At the sale of Crispiaen Colyn (20/3/1612), in which most of the subjects were mentioned and which contained very cheap paintings, the prices of the history pieces were generally between one and five guilders (many even less than a guilder), with a few peaks: 41-17 [41 guilders 17 stivers] for an Image of Mary ("een Marienbeelt"), 48-0 for an Adulteress ("een overspelent vroutgen"), 56-0 for a "Susanna", 63-0 for a "Crucifix," 80-10 for a Crucifixion of Christ on Mount Calvary ("Cruysinge Christi, berg van Calvarien"). Flower and fruit still lifes ("bloempotten" and "fruytagien”) are generally about one guilder, but 17 guilders was paid for a flower piece by Jacques Savery. The kitchen pieces are mostly around four guilders, with peaks of 28 and 35 guilders. Most landscapes are less than ten guilders, but there are a few between 10 and 20 guilders, with peaks of 27 and 28 guilders (both with the name of Pieter Stalpaert) and 36 guilders (no name). The numerous "heads" ("tronies") are mostly sold for less than one guilder. It is remarkable that in these sales, copies are explicitly mentioned several times (copies after Cornelis van Haerlem, Jan 
Bruegel, Abraham Bloemaert, Gillis Coignet and Pieter Gerritsz).

In the more "expensive" sale organized by Cornelis van der Voort (1614), a sale in which many subjects and quite a number of names are also mentioned, the prices of landscapes vary between 8-5 to 59 guilders: most of them are between 15 and 40 guilders (the most expensive is without a name: of the eight works by De Momper, the prices vary between 14 and 47 guilders). The kitchen pieces (all of them anonymous) are between 16 and 57 guilders, while the history paintings vary greatly in price: there are several of less than 10 guilders (and that could also include a "Mars and Venus"), but most are between 10 and 30 guilders. However, there are a few very expensive paintings (205 for a "Banquet" by Dirck Barentsz. and 317 guilders for a "Banquet of the Gods"). Also very expensive was a cavalry battle ("bataille") by Karel van Mander (221 guilders); although we also come across works of less than 10 guilders by the same artist. See, too, the following note. Further research about the prices at such auction sales is necessary.

${ }^{44}$ In most of these sales we find inexpensive to very cheap paintings; of the ca. 500 paintings sold between September 1608 and May 1609, the majority went for less than 20 guilders. But there are always more expensive works as well. However, the general level of prices could vary per auction sale. At the sale of Johanna Artsen and Jacques van der Lamen (30/9/1608), most of the prices were between 10 and 20 guilders, with only a few below 5 guilders; some were more expensive, however, costing between 30 and 50 guilders. We find exactly the same pattern in the following sale of Felix van Lun (2/10/1608).

Much cheaper were most of the works in the sales organized by Valerius van der Houven (29/10/1608 and 23/5/1609); most of the paintings went for less than 5 guilders, with a few exceptions between 20 and 50 guilders. The same holds for the sale of Pieter Loduwijcxs (24/2/1609), although the general level is a little higher, because more works were sold between 10 and 20 guilders.

Even cheaper were the paintings of the one-day sale of the widow of Hans van de Velde (the father of Esaias) on 23/2/1609. The prices were mainly between 1 and 3 guilders; only a few went for more than 10 guilders (the highest was 31 guilders). At the huge sale of Crispiaen Colyn we may notice the same phenomenon: most of the paintings are less than 5 guilders (many even less than 1); out of the more than 600 paintings, only 25 commanded between 10 and 20 guilders, 10 between 20 and 50, and 3 above 50 (the most expensive was 80-10).

Those sales are clearly different from that organized by Lucas Luce (16/3/1610); at that sale, most paintings went between 10 and 50 guilders - about as many between 10 and 20 as between 20 and 50. However, also in this case, there were many between 1 and 10 guilders, while 11 works were sold between 50 and 100 guilders, with peaks of 163, 180, and 232 guilders.

We find the same pattern in the sale organized by Cornelis van der Voort (7/4/1614): quite a few works sold between 2 and 10 guilders, but many more between 10 and 20, and even more between 20 and 50 guilders. Thirteen paintings commanded even higher prices (the highest at 106, 142, 205, 221, and 317 guilders!) A special case is the sale of Claes Rauwaert, probably largely composed of the estate of the collector (and also dealer?) Jacob Rauwaert (published in Bredius, Künstlerinventare, vol. 5, 1734-48). It mostly comprises expensive works that were collected in the last decades of the sixteenth century: 28 lots went higher than 100 guilders (the highest 455 guilders!) and about 45 were sold for prices between 50 and 100 guilders. However, even in this sale there were many pieces of less than 10 guilders (ca. 80 lots, among which were many roundels ["rondjes"] and small paintings representing firescapes ["brandjes"]). One wonders if those were also from the collection of Rauwaert - these inexpensive paintings might have been added to this 
sale.

${ }^{45}$ We find many landscapes and still lifes of this price level in both the "expensive" and "cheap" sales.

${ }^{46}$ The following are mentioned as painters, but they were certainly also active as dealers: Jan Basse (Rijsel 1572), Hans van Cleeff (Antwerp ca. 1570), Crispiaen Colyn (Mechelen 1574), David Colyns (Rotterdam 1582, son of Crispiaen), Hans van Coninxloo (Antwerp 1565), Lucas Luce (Antwerp 1575), Frans Kaersgieter (Belle 1573), Adriaen van Nieulandt (Antwerp 1586), Barent van Someren (Antwerp 1572), Anthony van de Velde (Antwerp 1557), Cornelis van der Voort (Antwerp 1576), Pouwels de Vries (Antwerp 1567); also the "antijcksnijder" Cornelis van der Bloocke (Mechelen 1569) and the goldsmith Pieter Coning (Antwerp 1578, father of Salomon Koninck) would have been active as dealers. Among the other regular buyers were undoubtedly many of Southern Netherlandish descent, for instance, the art lover and collector Hendrick van Os (Antwerp 1555/6; about him, see Bok, "Vraag en aanbod," 69-72). Briels mentions a few other merchants and buyers from the Southern Netherlands that we find bidding in these sales; see Briels, "De Zuidnederlandse immigratie," 106-12. Remarkably, men like Basse, Van Cleeff, Luce, and Van Someren, names we meet often in these sales, bought paintings in the cheapest category as well as very costly ones (the last ones by commission?).

${ }^{47}$ Briels, De Zuidnederlandse immigratie, 46-52; and J. G. C. A. Briels, "Brabantse blaaskaak en Hollandse botmuil. Cultuurontwikkelingen in Holland in het begin van de Gouden Eeuw," De zeventiende eeuw 1 (1985): 12-36. We find this strikingly phrased later by Gerard Brand in his Historie der Reformatie (1671), not as mockery or disapproval but as a historical fact: "The Brabanders and Flemish...brought splendor and costliness to the cities that housed them, enticing the natives to succumb to this vanity and also to opulence in meals and delicacies that in former days were unusual and unrespected in this country" (De Brabanders en Vlaemingen...brachten de pracht en kostelheit van klederen in de steden die hen herbergden, verleidende d'ingeborenen tot het misbruik derselve ijdelheit: ook tot d'overdaedt van maeltijden en lekkernijen, hier te lande eertijdts ongewoon en ongeacht). Quoted by Briels, "De Zuidnederlandse immigratie," 49; and Briels, Zuid-Nederlanders, 33.

${ }^{48}$ One of those who was cheated by Jerolimo is Otje Dickmuyl (Little Otto Fatface), an art dealer who had supplied him with a great number of good paintings to furnish the salon of his house "om een Sael te stofferen" (G. A. Bredero's Spaanschen Brabander, ed. C. F. P. Stutterheim [Culemborg: Tjeenk Willink/Noorduijn, 1974], 306-7, r. 2050-65; see also Briels, "De Zuidnederlandse immigratie," 106). Bredero, trained as a painter, would have been very familiar with this milieu of art dealers, as appears from the fact that he himself, "Garbrant Ariansz." was one of the buyers at the notorious sale of Johanna Artsen and Jacques van der Lamen in 1608 (see note 41 above,); this was noted by Van Eeghen, "Het Amsterdamse Sint Lucasgilde," 89.

${ }^{49}$ Among the paintings with names of artists (unfortunately only very few) in the above-mentioned sales, we find also very inexpensive works of well-known masters, often next to much more expensive works(especially from painters of Southern Netherlandish descent or training). For instance Jan Nagel (probably from Alkmaar, but Van Mander calls him a follower of the Antwerp painter Cornelis Molenaer; his work is mostly between 1 and 10 guilders, but can also command 44 guilders), Jacques Savery (Kortrijk 1565, as of 1585 in Haarlem, since 1589 in Amsterdam; almost all of his works realize 1 or 2 guilders), Pieter Stalpaert (Brussels 1572, since 1598 in Amsterdam; mostly between 25 and 50 guilders, but sometimes only 4 guilders). Karel van Mander probably worked for two different segments of the art market: the prices for his works are highly 
divergent; in the sale of Claes Rauwaert (26/8/1612) we find, for instance, 4 pieces of less than 10 guilders (one described as "a fire" of 4 guilders and 5 stivers), 11 between 10 and 20 guilders, and 5 between 20 and 50 guilders, among which another "fire" of 24 guilders and 5 stivers (the other works are not described). In the sale of Van der Voort (7/4/1614) a cavalry battle ("een bataille"), on the other hand, commanded 221 guilders!

${ }^{50}$ The local artist, who sold his own works directly from his shop, would have had one important advantage over masters from elsewhere whose paintings one bought at sales and markets: the buyers did not have to be afraid that they were being cheated with copies. Considering the insinuations of the Amsterdam guild members, this must have been an ever-present fear. Those who liked to buy a good painting but had no special expertise would have been stimulated to buy paintings by living masters who worked in one's own city. De Marchi argues that it was this uncertainty in particular that caused the growing importance of the role of expert art dealers, who could give some warranty of quality. See De Marchi, “The Role of Dutch Auctions," 208-12. ${ }^{51}$ Naturally, we also know these subjects from paintings of the second half of the sixteenth century that still exist, although it is remarkable that some types which turn up frequently in inventories and in sales are now virtually absent, such as the high numbers of "tronies" and the many inexpensive flower still lifes ("bloempotten") and fruit still lifes ("fruytagien").

${ }^{52}$ Montias suggested that the impulse for process innovation "may have been primarily artistic rather than mercenary" (Montias, "Cost and Value," 460). See also E. Melanie Gifford, "Esaias van de Velde's Technical Innovations: Translating a Graphic Tradition into Paint," in Painting Techniques: History, Materials and Studio Practice, ed. A. Roy and P. Smith, Contributions to the IIC Dublin Congress 7-11 September 1998(London, 1998), 145-49, who interprets the technical innovations of Esaias entirely as an artistic process.

${ }^{53}$ Van Mander writes this of, for instance, Jacob Grimmer, Cornelis Molenaer (Schele Neel [Cross-eyed Neil]), and Joos van Liere (Van Mander, Het leven, fol. 256v and 257r); Orlers would write the same several decades later about Van Goyen (Orlers, Beschrijvinge der stad Leyden, 373). With regard to strategies of innovative behavior on a competitive art market, see Neil de Marchi and Hans J. van Miegroet, "Art, Value, and Market Practices in the Netherlands in the Seventeenth Century," Art Bulletin 76 (1994): 451-64. See also Bok, "Vraag en aanbod," 190. For the concept of "liefhebber" (lover of art), see Bok, "Vraag en aanbod," 73-75.

${ }^{54}$ See note 1 above.

${ }^{55}$ For biographical data, see George Keyes, Esaias van de Velde, 1587-1630 (Doornspijk: Davaco, 1984), 18-26. Concerning the sale of "the widow...[not filled out] at the Sleutelbrugge," who can be identified with Cathalyne van Schorle, widow of the then recently deceased Hans van de Velde, see note 41 above.

${ }^{56}$ For a technical description of early work by Esaias (in some of these works he goes remarkably far in experimenting with a sober technique), see Gifford, "Esaias van de Velde's Technical Innovations," 146-48. For a description of Roelant Savery and Esaias van de Velde, see E. Melanie Gifford, "Jan van Goyen en de techniek van het naturalistische landschap," in Jan van Goyen, ed. C. Vogelaar (Zwolle/Leiden: Stedelijk Museum De Lakenhal, 1992), 71-74. We meet for instance in his early work with one thin layer of a light brown color applied as underpainting for the entire landscape, brushed over a quickly drawn sketch on a white ground. Over this underpainting the landscape is painted with thin browns, grays, and greens (Gifford, "Esaias van de Velde's Technical Innovations," 147). In other early works he applied several transparent "washed" tones (for instance grayish under trees, brownish under architecture) on a light-colored ground, over which 
the landscape was painted wet in wet (Gifford, "Jan van Goyen en de techniek," 72-73). The figures were always painted after he finished the landscape and are not present in the underdrawing. Gifford also describes an experiment with black paint being rubbed in the (poplar) panel, which was then covered with a thin layer of paint through which the wood grain would intentionally remain visible (ibid., 147). I am grateful to Petria Noble of the Mauritshuis, with whom I scrutinized a painting by Esaias van de Velde, which was painted in more or less the same technique as indicated above.

${ }^{57}$ See, for instance, Landscape with Castle Abtspoel (Keyes, Esaias van de Velde, cat. no. 18, colorplate $\mathrm{X}$ ), a rather large canvas that was undoubtedly painted on commission. There certainly is no question of progressive or regressive stylistic development: in the same year we find small, quickly made, inexpensive works. Also late in his career he continued to work in these two manners (Gifford, "Jan van Goyen en de techniek," 149).

${ }^{58}$ Montias, "Cost and Value," passim.

${ }^{59}$ Van Mander, Het leven, 256v: "In eenen dag als men hem te voor wat had aengeleyt, maeckte hy een groot schoon Landtschap." Van Mander begins this sentence by saying: "He worked in the manner of those who painted with water colors, without maulstick, and was miraculously quick, working for one or the other at a daily wage" (Hy wrocht op de Water-verwers maniere, sonder maelstock, en was wonder veerdigh, werckende voor d"een en d"ander in dagh-huyr). He added (following the quotation in the text): "and one paid him for a whole day one thaler, sometimes for a background or a ground seven stivers" (en men gaf hem van eenen heelen dagh eenen Daelder, t"somtijts voor een achter-uyt, ofte gronded seven stuyvers). He was very good-natured and was often imposed upon by other painters, Van Mander says. He was also poor because he drank. Van Mander mentions Jan Nagel as a follower who never equaled him as a landscape painter but was better in figures. Nagel is a painter whose name we meet in Amsterdam with lowly priced landscapes: in two sales of 1614 there were 12 pieces of between 12 stivers and 12 guilders, and one piece of 44 gulden (see Obreen, Archief, vol. 4, 47).

${ }^{60}$ Also at the Amsterdam sales discussed above - in which very few names of artists are mentioned - his name turns up in the sale of Cornelis van der Voort on 7/4/1614 (with landscapes of 26 and 36 guilders respectively). A landscape with the monogram CM, representing the Good Samaritan, has always been attributed to him (Berlin, Staatliche Museen, $101.5 \times 152.5 \mathrm{~cm}$, the figures have been attributed to Maerten van Cleve); see H. G. Franz, Niederländische Landschaftsmalerei im Zeitalter des Manierismus (Graz: Akademische Druck-und Verlaganstalt, 1969), 23842 and fig. 373, who describes it as being very "progressive" and anticipating later work by Hans Bol. However, in the catalogue of the Staatliche Museen of 1976 (cat. no. 706), the attribution is doubted, and it is suggested that the landscape dates from the early seventeenth century (judging from the reproduction, this seems to me highly unlikely). Miedema is sceptical about the attribution, since the monogram CM can stand for many artists; see Hessel Miedema, Karel van Mander: The Lives of the Illustrious Netherlandish and German Painters (Doornspijk: Davaco, 1997), vol. 4, 156-57.

${ }^{61}$ Van Mander, Het leven, fol. 256v: "alle dinghen seer eyghentlijck het leven volghende, "tzy in huysen, verre Landtschap, oft voorgronden."

${ }^{62}$ Van Mander, Het leven, fol. 257r: 'een seer goet Schilder van Landtschap, volghende seer de manier van Pieter Brueghel [...] had oock verscheyden Landen besocht, en verscheyden ghesichten nae "tleven gedaen. Hy wrocht in Water en in Oly-verwe, op een schoon en veerdige maniere." Luuk Pijl rightly remarked that one could easily make the mistake of placing this painting in 
Haarlem around 1625 if it had not been signed and dated (Luuk Pijl, "Over de chronologie van de schilderijen van Hercules Segers," Bulletin van het Rijksmuseum 13 [1995], 172-80, esp. 177). See also Albert Blankert, Museum Bredius: Catalogus van de schilderijen en tekeningen (Zwolle: Waanders, 1991), 45, who remarked that this little painting seem to be "a precursor of some works by Jan Brueghel and the 'realistic' landscapes that follow, by Jan van Goyen and Esajas van de Velde," quoting Martin who already pointed out how extraordinary this landscape is. Strangely enough, this was not taken up by Keyes, who does not mention Pieter Balten in his monograph on Esaias van de Velde (Keyes, Esaias van de Velde). It is possible that the "Mr. Balten" mentioned in the St. Luke's guild of The Hague at the end of the sixteenth century (Obreen, Archief, vol. 3, 286), is the same as this Pieter Balten from Antwerp.

${ }^{63}$ The technique probably approaches that of many small landscapes by Esaias van de Velde (see note 56 above). The paint layer is so thin that the brushstrokes of the ground are also clearly visible. I am grateful to Petria Noble with whom I carefully analyzed a transparency of this stolen painting.

${ }^{64}$ For De Momper, see Klaus Ertz, Josse de Momper de J. (1564-1635) (Freren: Luca Verlag, 1986). The paintings that are dated early in De Mompers career by Ertz seem to be most quickly and thinly painted. De Momper's works turn up several times in the sales discussed above (prices between 14 and 40 guilders; see Obreen, Archief, vol. 6, 46). Montias even established that in Amsterdam inventories between 1620 and 1650 no painter was as often mentioned as De Momper; see John Michael Montias, "Works of Art in Seventeenth-century Amsterdam: An Analysis of Subjects and Attributions," in Art in History, 331-72, esp. 364.

${ }^{65}$ A long time ago Blankert referred to similar motifs in the works of Brabant predecessors, in particular in the work of Jan Brueghel, in his comments on Stechow's book: Albert Blankert, "Stechow: addenda," Simiolus 2 (1967/68): 108. See also Briels, "De Zuidnederlandse immigranten," 91-93.

66 "Vele ende seer fraeye gheleghentheden [...] gheconterfeyt naer dleven, ende meest rontom Antwerpen gheleghen sijnde." The Latin title: Multifariarum casularum ruriumque lineamenta curiose ad vivum expressa. The title print of the second series: Praediorum villarum et rusticarum casularum icones elengantissimae ad vivum in aere deformatae. (In all cases, it is emphatically mentioned that they were made "from life.") Both series are reproduced in R. van Bastelaer, Les estampes de Peter Bruegel l'ancien (Brussels: Van Oest, 1908). See the following note as well.

${ }^{67}$ All twenty-five etchings by Visscher are reproduced in Hollstein, vol. 34, nos. 292-317. Seven prints of Cock's second series were skipped: one comes from the first series (no. 316), and one is his own invention (no. 317). The inventor of the two series published by Cock is nowadays mostly named "Master of the Small Landscapes." In the course of time Cornelis Cort, Hans Bol, Cornelis Massys, Cornelis van Dalen, Joos van Liere, and Hieronymus Cock himself have all been proposed as inventor. See, among others, Dutch Landscape: The Early years, Haarlem and Amsterdam 1590-1650, ed. C. Brown (London: National Gallery, 1986), 110-11; see also 18-19, for the impact of the series on painting in the Northern Netherlands, which was emphasized by many others as well.

${ }^{68}$ A good example of nostalgia is found in a few lines by Jacob Duym (Jacob Duym, Het moordadich stuck van Balthasar Gerards, published in 1606; quoted by Briels, Vlaamse schilders in de Noordelijke Nederlanden, 436): "Farewell, beautiful Brabant, farewell Antwerp great, / Farewell beautiful city, where we earned great fortunes / From where we traded with all parts of the world, / Farewell lovely, pleasant country and lovely, beautiful rivers, /... / Farewell fine country where we 
thought we would die." (Nu adieu Brabant schoon, adieu Antwerpen groot, / Adieu schoon stad, daer wy in wonnen schatten bloot, / Van waer den handel was op allerley quartieren, / Adieu soet lieflijck Land en soete fray rivieren, / ... / Adieu schoon Land, daer wy al meynden in te sterven). ${ }^{69}$ See, for the last two, Boudewijn Bakker and Huigen Leeflang, Nederland naar 't leven. Landschapsprenten uit de Gouden Eeuw (Zwolle/Amsterdam: Museum het Rembrandthuis, 1993), 54-57, with further references. The Amsterdam series was produced before Visscher published the copies of the "Small Landscapes," and the drawings of the "Pleasant Places" ("Plaisante Plaetsen") would have been made earlier as well. (The five drawings that we still know bear the date 1607). It is clear that Galle's reissue must have been the direct source of inspiration. Although the compositions of Visscher's drawings immediately become more open and different in character in several respects, there is great similarity in motifs and composition, especially in the four Amsterdam prints and Hollstein nos. 148 and 195. See also Luijten et al., Dawn of the Golden Age, 651-55. For a considerable number of such series, see also Catherine Levesque, Journey through Landscape in Seventeenth-century Holland (University Park, Pa.: Penn State Press, 1994).

${ }^{70}$ In two laudatory poems on the city of Haarlem which Van Mander composed around 1596, we notice how he shows himself an ardent advocate of his new hometown and the pleasant surroundings of that city; see Leeflang, "Dutch Landscape: The Urban View," 64-66. In Strijdt tegen onverstandt (in Den Nederduytschen Helicon; quoted by Briels, Vlaamse schilders in de Noordelijke Nederlanden, 436), Van Mander emphatically replaces nostalgia for the lost country with love for the new fatherland.

Series like the Plaisante Plaetsen, in which local Haarlem traditions play a role, may have had a particular resonance for the contemporary viewer as well; for this, see especially the fine article by Leeflang. The recommendation "from life," already inscribed emphatically on both title prints of the "Small Landscapes" (and about which Van Mander writes often when discussing the Antwerp landscape painters mentioned above), returns frequently on the title pages of print series after Visscher and Van de Velde. For the importance attached to representation "from life" and the implications thereof, see Boudewijn Bakker, "Nederland naar 't leven: een inleiding," in Bakker and Leeflang, Nederland naar 't leven, .6-17; and Boudewijn Bakker, "Levenspelgrimage of vrome wandeling? Claes Janszoon Visscher en zijn serie Plaisante Plaetsen," Oud Holland 107 (1993): 97-115. The connection with Calvinist thought that Bakker underlines should remind us of the fact that the immigrants were mostly Calvinist. This could endorse the supposition that in those circles in particular one would have been interested in local landscapes depicted "from life." ${ }^{71}$ See, for instance, Hessel Miedema, "Dageraard der gouden eeuw," De Zeventiende Eeuw 10 (1994): 241-51, esp. 248: "a lay public...that did not pretend to know about paintings, or even to need any knowledge of it" (een lekenpubliek dat...niet pretendeerde er verstand van te hebben, of er zelfs verstand voor nodig te hebben).

${ }^{72}$ Lawrence Goedde pointed out this phenomenon in connection with Goltzius's drawing of landscapes around Haarlem in the first years of the seventeenth century, which seem to appear out of nothing; Lawrence O. Goedde, "Naturalism as Convention, Subject, Style, and Artistic Self-consciousness in Dutch Landscape," in Looking at Seventeenth-century Dutch Art: Realism Reconsidered, ed. W. Franits (Cambridge: Cambridge University Press, 1997), 129-43 and 231-33.

${ }^{73}$ Compare my argument with reference to the "simple" landscapes by Van Goyen, which must have appealed to an audience of connoisseurs as well: E. J. Sluijter, "Jan van Goyen als marktleider, virtuoos en vernieuwer," in Jan van Goyen, 38-59, esp. 45-54. See also Goedde, "Naturalism as Convention," 142-43. 
74 "As he used to say, he had learned from his own lack of experience that nobody was qualified to judge the art of painting (with which one is nowadays confronted everywhere), who did not, in one way or another, learn from practice the basics of that art. He had noticed how important men, famous for their all-round education, made themselves ridiculous in the eyes of practitioners of the art by giving with great authority their opinion on the art of painting." Kan, De jeugd, 65; and Heesakkers, Mijn jeugd, 70-71.

${ }^{75}$ After having stated that, concerning all those painters, their fame should speak for itself, and that the fame of Van Poelenburch, Wttenbroeck, and Van Goyen truly is quite something, Huygens writes: "Instead of mentioning all, I will foreground only two of them: Jan Wildens and Esaias van de Velde and I would place them almost at the same level as Paulus Bril, also from the Netherlands, but deceased in Rome. One could even say that in terms of naturalness nothing lacks in the works of those exceptional painters, except for the warmth of the sun and the gentle breeze." Kan, De jeugd, 73; and Heesakkers, Mijn jeugd, 79.

${ }^{76}$ See Sluijter, "Jan van Goyen als markleider," 38-39.

${ }^{77}$ Orlers, Beschrijvinge der stad Leyden, 373. About Pieter de Neyn he also writes that his landscapes, which he "could make with great speed, were found appealing by art lovers and burghers" (met groote vaerdigheyd [snelheid] conde maecken, de Liefhebberes ende Burgeren zo aengenaem waren).

${ }^{78}$ Kan, De jeugd, 66; and Heesakkers, Mijn jeugd., 72.

${ }^{79}$ For the associations with the "neat" ("nette") manner of painting with an illustrious, indigenous tradition, see E. J. Sluijter, De lof der schilderkunst: Over schilderijen van Gerrit Dou (1613-1675) en een traktaat van Philips Angel uit 1642 (Hilversum: Verloren, 1993), 56-65. Added 2008: English translation, E. J. Sluijter, "In Praise of the Art of Painting: On Paintings by Gerrit Dou and a Tretise by Philips Angel of 1642," chapt. 7 in Seductress of Sight: Studies in Dutch Art of the Golden Age (Zwolle: Waanders, 2000).

80 "Hier sijn oock schilderijen bij meenichte te krijgen. Hebben hier teegenwoordich van de beste meesters woonen." She continues by writing: "Last week there was a market here, which one calls the Lent Market, and I saw a great many fine pieces, and I had someone with me who knew about paintings, and at Pentecost there is again a market, because there is a market three times a year. Although some things might be better available with you [in Antwerp], the costs of transportation would not compensate this - apart from the fact that you would have the trouble of dragging everything in and out of ships which is a great nuisance" (Was hier verleede weeck mart, dat men noemt de Vaste Marckt, sach bij hoope fraye stucken, alsoo een bij mij hadt die daer kennis van heeft en te Pinsteren ist hier weer mart alsoo 3 mael "s jaers marckt is. En offschoon eenige dingen daer bij UL wat beter koop soude mogen sijn, neemt de onkosten vant overvoeren weer wech. Behalleven UL de moeiten heeft van tsleepen uit en in de scheepen daart ook seer mee versuckelt). I. H. van Eeghen, "Magdalena Stockmans," Maandblad Amstelodamum 41 (1954): 137-41, esp. 140. Magdalena Stockmans was the widow of the rich merchant Isaac van der Voort. She had returned with her children from Naples (where she had lived for eleven years) shortly before and stayed in Antwerp. It is likely that she did not have the chance to bring many of her belongings on this long journey to the north. Her sister rented a house for her in Amsterdam and advised against buying furniture and paintings. It was self evident that paintings belonged among the very first things that had to be purchased! 
Recommended Citation:

Eric Jan Sluijter, "On Brabant Rubbish, Economic Competition, Artistic Rivalry, and the Growth of the Market for Paintings in the First Decades of the Seventeenth Century," JHNA 1:2 (Summer 2009), D0I: 10.5092/jhna.2009.1.2.4 